\title{
TRANSFORMATION OF TOOLS AND CONSERVATION OF ARCHITECTURE ${ }^{\#}$
}

\author{
SOME RESEARCHES ON THE USE \\ OF DIGITAL SYSTEMS FOR THE INTERVENTION \\ ON THE HISTORICAL BUILDINGS
}

\author{
DONATELLA FIORANI* ${ }^{*}$ - MARTA ACIERNO ${ }^{* *}$ \\ SILVIA CUTARELLI ${ }^{* * *}-$ ADALGISA DONATELLI****
}

\begin{abstract}
"PhD, Full professor, Department of History, Representation and Restoration of Architecture, Sapienza University of Rome, Piazza Borghese 9, 00186 Rome, Italy. E-mail: donatella.fiorani@uniroma1.it ${ }^{* *} \mathrm{PhD}$, Researcher, Department of History, Representation and Restoration of Architecture, Sapienza University of Rome, Piazza Borghese 9, 00186 Rome, Italy. E-mail: marta.acierno@uniroma1.it ${ }^{* * *} \mathrm{PhD}$, Architect, specialised in Architectural Conservation, Department of History, Representation and Restoration of Architecture, Sapienza University of Rome, Piazza Borghese 9, 00186 Rome, Italy. E-mail: silvia.cutarelli@uniroma1.it ${ }_{* * * *} \mathrm{PhD}$, Researcher, Department of History, Representation and Restoration of Architecture, Sapienza University of Rome, Piazza Borghese 9, 00186 Rome, Italy. E-mail: adalgisa.donatelli@uniroma1.it
\end{abstract}

The use of digital technologies to study architecture and landscape has begun to represent an innovative aspect of the research when it started to allow the dynamic association (as input and output) of images and alphanumeric data: the different combination of this information through inferences and algorithms and the consequent generation of new data has freed digitisation from a strictly instrumental role making it a new methodological approach in itself.

As a matter of fact, recently architectural research has begun to take an interest in the problem 'from within', working not only on the application of computer tools but, more consciously, on their configuration. The work carried out by the Sapienza research group is aimed at developing ontologies and inferential models specifically dedicated to the representation of historical buildings and is devoted to the implementation of a national GIS platform for the historical centres, the Risk Map of the Italian Ministry of Cultural Heritage and Activities and Tourism.

This kind of work involves a series of methodological issues specially oriented to the definition of the role of the history of architecture in itself and its use for the conservation project. These arguments are developed within this essay, mainly focused on: type and quality of information deriving by the new procedures; interpretative components that fuel the new research methods; cost/benefit ratio in the use of 'analogue' and 'digital' approaches; future prospects of the two different (traditional and digital) investigative strategies. Moreover, both of the fields of digital research developed by the group (ontology and Risk Map) are here summarised.

Keywords: digital humanities, architectural conservation, methodology history of architecture, historical center

\footnotetext{
\# This publication was supported by the National Cultural Fund of Hungary (NKA) under Grant Number 101108/547.

$\bowtie$ Corresponding author.
} 


\section{PROBLEMS AND OPPORTUNITIES REGARDING THE USE OF DIGITAL TOOLS FOR RESTORATION IN ARCHITECTURE (D.F.)}

The use of digital technologies to study architecture and land is not per se an innovative aspect of research. If we consider the most widespread applications in the field of image processing, such use instead appears to be the latest modification of tools and codes to represent the world, following on from methods that have been replaced over time, from cave drawings to computer-aided design. Rather, it is the dynamic association (as input and output) of images and alphanumeric data, the different combination of this information through inferences and algorithms, and the consequent generation of new data - appropriately geo-referenced or explained by alphanumeric or graphic methods - that frees digitisation from a strictly instrumental role in order to make it a new methodological approach in itself.

In the architectural field, attention to the expressive potential of the image has long prevailed over interest in accessory information, which cannot be visualised except by means of graphic and symbolic summaries, while the predominantly applicative nature of many experiments has implicitly facilitated delegation to other scientific fields when it comes to questions raised by the use of quantitative and statistical methods to select, collect and manage such information.

These methods, which have traditionally been adopted for hard sciences and for many statistical evaluations involving medical, economic, social and anthropological research, have also been tested for some time in the linguistic, archaeological and historical fields, albeit in a prolonged dialectic that contrasts the quantitative and qualitative aspects of the research ${ }^{1}$. The issues of heuristics, data archiving and extraction, analysis and presentation of the results of studies that form part of the so-called digital humanities have also been discussed in architectural, urban and territorial contexts, in particular related to history ${ }^{2}$, restoration and urban planning, initially focusing on the analysis and processing of images and texts. While the study of the representation of the existent has naturally been accompanied by a parallel path involving the creation of design images, the definition of a specific domain dedicated to the description of buildings and their structural and decorative components, with dictionaries and thesauruses ${ }^{3}$, has radically renewed a process of identification communicated, especially since the Renaissance, through treatises and manuals.

The availability of tools for graphic and alphanumeric representation such as the Geographic Information System (GIS) and Building Information Modelling (BIM) and their application in spatially defined contexts (spatial humanities) have subse-

\footnotetext{
${ }^{1}$ Adamo-Gregory 2000.

${ }^{2}$ Lelo-Chodějovská 2014. 4.

${ }^{3}$ Among the first proposals we remember the TAU Project (TAU - Thesaurus Artis Universalis), which was promoted by the Comité Iternational d'Histoire de l'Art (1983). Today the Art \& Architecture Thesaurus, by the Getty Research Institute, is one of the most advanced systems; it is available on web at $<$ https://www. getty.edu/research/tools/vocabularies/aat/> (Accessed 29 December 2019).
} 
quently prompted architectural historians and restorers to reflect on the use of these systems, starting from the results of their application on pre-existing buildings' tissues and fabrics ${ }^{4}$, helping to develop analysis in relation to 'networks' and interconnected spaces ${ }^{5}$.

More recently, architectural research has begun to take an interest in the problem 'from within', working not only on the application of computer tools but, more consciously, on their configuration ${ }^{6}$. An attempt has therefore been made to improve the flexibility and interoperability of digital systems through the study of ontologies and inferential models designed to represent historical buildings. At the same time, control of data processing methods through the use of specially developed algorithms has been progressively refined and new attention has been paid to the question of 'filing' the asset or rather translating reality into a discretised language expressed by terms that are univocally recognisable, hierarchised and related to each other through established rules. The definition of the form has thus evolved from a very traditional protection tool into one of the cornerstones around which potential processing of data entered into the digital system is organised.

The work carried out by this research group falls within the latter category: on the one hand, it is aimed at developing ontologies and inferential models specifically dedicated to the representation of historical buildings and, on the other hand, it is devoted to the implementation of a national GIS platform, the Risk Map of the Italian Ministry of Cultural Heritage and Activities and Tourism ${ }^{7}$.

Before summarising certain aspects of the work undertaken, selected on the basis of their relevance to historical and architectural research, it is necessary to clarify its premises, content and objectives by considering the comparison between innovative methodological contributions and 'traditional' research strategies. The following areas have been taken into particular consideration: the ability to acquire information with the new procedures that is comparable, in terms of type and quality, with that derived from traditional systems; the interpretative components that fuel the new research methods; the cost/benefit ratio in the use of 'analogue' and 'digital' approaches; the future prospects of the two investigative strategies.

With reference to the type and quality of the collected information, it should be noted that the new formal structures put in place for digitisation essentially derive

\footnotetext{
${ }^{4}$ See for instance Tamborrino 2014 and especially Stabel 2014. A short synthesis of the main related issues is also offered by Marmor 2016.

${ }^{5}$ In Drucker et al. 2015 we can find an overview of the research projects developed in the United States, ordered in four categories: 'text analysis', 'spatial analysis', 'network analysis' and 'image analysis', with some observations about their use.

${ }^{6}$ This approach marks the passage from the information technology 'for' the history and conservation of architecture to the information technology 'with' both disciplines, recovering the suggestion in CelentanoCortesi 2004, mainly related to the humanistic sciences. The use of the proposition 'with' underlines the passage from a simply pragmatic attitude to this kind of work to a real interdisciplinary approach.

7 This work has been published in different essays, among which we refer to Acierno et al. 2017; FioraniAcierno 2017; Fiorani-Acierno 2019; Fiorani 2019. It has allowed the implementation of the Italian Risk Map on the historical centres: <www.cartadelrischio.beniculturali.it> (Accessed 29 December 2019).
} 
from the "empirical bases of research": from these, they deduce how to pose and analyse problems, the semantic and logical organisation of reasoning and the inferential strategies that are scientifically appropriate to offer answers to the issues addressed. In other words, the construction of the digital system develops "a sort of hermeneutics of argumentation in which the primary difficulty is to make the unspoken explicit and to restore the implicit of assumptions and cognitive ellipses" ${ }^{\text {". }}$. In this sense, ontologies, algorithms and filing methods feed on the relationship mechanisms represented by traditional logics, even though their nature causes a substantial transformation of the forms and content of the research.

New key issues concern, among other things, the ownership of the sources that can be used as data, a problem that historians in particular have investigated in depth. There is an opposition between those who only wished to consider reliable 'digital' sources to be faithful reproductions of ancient documents, which can be infinitely investigated in all their aspects with the exception of strictly material content ('source-oriented'), and supporters of the intrinsic validity of the data extracted from the same document and represented through appropriate formalisations ('model-oriented' $)^{9}$. The question also arises in architecture, where the status of the document is shared both by written texts and by buildings' structural and material evidence. In the latter case, the reproduced digital source suitable for the 'source-oriented' choice should be a perfect three-dimensional rendering obtained from a laser scanner survey completed by detailed photomaps (even if this reproduction is significantly more complex than that of a simple text document, it should generally provide a laborious reproduction of the building including all internal spaces and would only be allowed if these spaces are fully accessible $)^{10}$. Even so, however, the three-dimensional model simply reproduces the outer shell of the structure, which can only be used for studies of a geometric, figurative and perhaps typological nature, but is certainly insufficient for adequate knowledge of the structure. We can therefore affirm that, especially for historical architecture, the option of source-oriented computer research comes at a great cost in terms of simplification, working on models that dematerialise and approximate the existent beyond what is acceptable for a deep understanding of $i^{11}$.

The use of model-oriented digital technologies, through the definition of specific formalisations, requires, on the other hand, decoding of historical architecture through

\footnotetext{
${ }^{8}$ Borillo 1984. 5-7, quoted in Panzeri 2005. 170.

${ }_{9}$ The distinction of digital methodologies in 'source oriented' or 'model oriented' is in Thaller 1989. See also the observations in Vitali 2009, with an effective synthesis of the following debate.

${ }^{10} \mathrm{Of}$ course, we aim to consider the $3 \mathrm{D}$ representation not as a simple and rough virtualisation of a given site, but as a real object of study, which could be used in substitution of the existing physical reality. In other terms, we should think to work with this model deriving from it the same patrimony of knowledge we could get using the traditional system of direct survey. This survey was used either for the graphic representation or for the deep understanding of the nature of the architecture, as illustrated in Hajnóczi 1956.

${ }^{11}$ A reflection about the issues involved by a not controlled de-materialisation of architecture is in Fiorani 2014.
} 
a process that 'discretises' the continuum of the real using uniform descriptive codes that can be correlated with each other. This fundamental process must be continuously calibrated on the appropriate analytical definition scale; within this scale, the univocal - and universally recognisable - correspondence between the description and the physical component described must be guaranteed, as well as the effectiveness of the relationship rules established between different components, to ensure the effective integral representation of the whole.

The particular 'connotative' rather than 'denotative' nature that characterises the study of the history of architecture and, therefore, of restoration, makes the dualism between object and interpretation more precarious, as is often the case in the digital humanities. This leads to evident difficulties at an epistemological level, necessitating the support of strong references that are accepted by all, some of which can only be expressed thanks to criteria established by specific public institutes ${ }^{12}$, while others are inexorably entrusted to shared interpretation as an expression of the culture of the time $^{13}$. These conditions make organising all digital systems both transitory (due to the need to ensure that the cultural premises that inspired them are continuously updated, as well as constant technological innovation) and permanent (due to the ability to safeguard the conservation of the data collected there). The same problems have been partially expressed in the historical and artistic field, sometimes even taking architecture into account ${ }^{14}$, but without considering its specific investigative features.

Proponents of the model-oriented system place great emphasis on the novelty of the operational scenarios enabled by digitised procedures. The computational power of modern computer systems makes it possible to carry out statistical comparisons and evaluations that were previously difficult to manage: targeted extraction of information related to a particular type of church structure can better clarify the extent and reason for the influence of a particular cultural model in the area, while distribution over time of different stone materials or mortar blends can help to define building (and economic) transformations in specific contexts. These results are based on the prior selection of the entries necessary for the system and on the interpretative method of the person filling in the form, two fundamental stages of the knowledge

\footnotetext{
${ }^{12}$ Generally, these are the Institutes involved in the cataloguing of the heritage; Panzeri 2005.

${ }^{13}$ Matthew Lincoln observed that "physical objects resist both the structured description and the abstraction these methods rely upon. Compared to structured data for libraries' generally homogeneous collection of books, museums do not yet have interoperable standards for describing their heterogeneous collections of unique objects. While library data are produced through broad consensus about the facts of a book's publication and classification, knowledge about historical objects tends to be advanced through iterative and conflicting scholarly argumentation - a process that is difficult (though not impossible) to model as structured data" (Drucker et al. 2015. 5).

${ }^{14}$ Johanna Druker has proposed to distinguish the 'digitalized' and the 'digital' history of art. The first is enumerated and visualised by the computer, the second is reconsidered on the basis of the new possibilities given by the information systems. Reflexions on this proposal are in Shelbert 2017.
} 
process which, together with the definition of the procedures with which the information is connected, reveal the 'non-neutral' nature of the data ${ }^{15}$.

It is precisely the translation of physical (concrete and tangible) reality into a series of 'data' - i.e. into information that is 'objectified' and therefore can be computed and compared - that constitutes the critical hinge of the digitisation process ${ }^{16}$; in this sense, as is often also the case in the hard sciences, computation and critical synthesis appear to be two sides of the same coin. Digitised systems that deal with architecture, in particular, are characterised by the structural overlapping of at least three levels of interpretation: the first relates to their formalisation, the second to the data input stage and the third to analysis of the results produced by inferential systems, which in turn become 'sources' ${ }^{17}$.

The first and third levels above all represent hidden steps that contain many hypostatised critical choices. We can provide some examples of this, considering concrete problems and possible solutions at an operational level.

A wall discontinuity can indicate a construction interruption, which may be due to technological choices that make the building more adaptable to possible differential settlement, as is the case in historical Venetian buildings, or may derive from distinct construction phases. The assessment 'in favour' or 'against' the construction solution in terms of structural vulnerability could be affected by excessive simplification resulting from formalisations, inferential chains or algorithms based on a unidirectional interpretative logic, which considers only the weakening effect produced by building discontinuity, especially in the presence of horizontal pressures. The awareness of this risk of interpretative fallacy must invite a conscious and critical approach to reading data, which often finds an adequate response in the interaction between historical knowledge and building-structural considerations.

Similarly, the rendering of the stratigraphic succession of masonry that can be observed on a wall can be inferentially recomposed using modelling created by a specific ontology. We know, however, that this interpretative method, developed in the archaeological field, works well when dealing with uniform two-dimensional layers, but may be more difficult to apply to the three-dimensional structure of the wall, especially when the two opposing sides of the masonry have undergone different transformations. In this case, we will find ourselves faced with two stratigraphies of the same wall that do not fully correspond to each other; they may be possible to understand through complex modelling refinement, as well as through the simple 'analogue' recomposition of the data, supplemented by a deeper knowledge of the core and the intersecting links between the walls.

The risk of a misleading reading is less insidious when entering data into the computerised system because it is more obvious and controllable: for example, an

\footnotetext{
${ }^{15}$ Settis 2002.

${ }^{16}$ Schöch 2013.

${ }^{17}$ As Vitali has observed "processes of digital elaboration change the statute of the sources". (Vitali
} 2009. 15.) 
isolated tower may be an independent defensive structure or the remains of a partially destroyed fortified complex, but trained operators must be aware of the need to subordinate their choice of type to a sufficiently comprehensive and convincing rendering of the construction phases. The choice, which is designed to extract data that identifies the fortified system within a defined area and time period, will in any case be bound by the possibility, whether initially planned or not, of identifying several types of system linked to past and contemporary configurations.

The proposed examples show how the interaction of scholars with the digital system, far from being a passive method, is constantly configured through conscious assessment of the work ahead.

The cost/benefit comparison of the results of investigations using traditional and digital tools should be considered from several perspectives. As noted above, the acquisition of an effective epistemological awareness may require, before studying the specific architectural or urban object, an understanding - and/or control - of the architecture of the digital system used, with a clear increase in investigative work. Indeed, this aspect embodies the paradox of a formalisation which, as stated above, must use an explicit rendering of implicit intellectual processes in order to be established, but which is used 'in the field', employing inferential steps, filters or algorithms that are not evident and can only be properly managed with the joint contribution of an expert scholar in the subject and a computer scientist. On the other hand, computation makes it possible, for instance, to directly overlap historical and construction data to that relating to the structural and thermal properties of the buildings or the area's geological and seismic characteristics. This provides very useful information for conserving the asset which, in the traditional management of design and planning, are often confined to the realm of various specialist knowledge. In general, the wide range of possibilities - in terms of the number of cases that can be considered and type of processing - to make comparisons between assets and their constituent features, as well as the ability to check the accuracy of the investigative results by cross-referencing different types of findings, make it possible, in the long term, to configure a completely new set of information and shared, synchronic and diachronic interrogation processes, the potential of which may still be unimaginable.

It is easier to predict the indispensable activities to promote the spread and correct application of the new investigative methods. These include the containment and control of the analytical process, which can potentially be infinitely extended - at the risk of becoming redundant and therefore useless -; the sharing of data representation models, which is essential for the effectiveness and possibility of exchange (interoperability); the commitment to systematically collect information on an asset at least every time that direct work is carried out on it.

The comparison between traditional and digital research must not, however, be considered in terms of the dominance or redundancy of one of the two paths. Today it seems quite likely that the two methods are destined to coexist, meeting different purposes and needs. A predominantly narrative historiographic path may therefore 
remain as a philological and critical activity, whose task will be to update the cultural perspectives of our time and, if necessary, to 'promote' - through appropriate communication - built heritage to a wider public. On the other hand, the use of digital tools seems to be mainly aimed at 'applied history' methods, which are better suited to restoration and conservation. The actual potential of history as 'narrative', due to its predominantly analogical nature, and of the 'applied' history, which must be managed digitally, will largely depend, however, on the understanding of their respective limits and on mutual acceptance, which, moreover, are also necessary conditions to guarantee their reciprocal and effective influence.

The extensive work carried out on ontologies for the interoperability of information systems that can be used for restoration and for filing and processing data contained in the Italian Risk Map system dedicated to cultural heritage is described in the following three paragraphs. These paragraphs, in summarising the content and themes covered, focus in particular on the processing of historical and structural information regarding ancient buildings.

\section{COMPUTER ONTOLOGIES FOR ARCHITECTURAL CONSERVATION (M.A.)}

One of the major issues featuring information and communication technologies for cultural heritage is the complex interaction between different and complementary information, originating from various systems often scarcely interoperable.

This condition can be effectively addressed by computer ontologies that are formalised conceptual representation schemes, able to fully describe different cultural environments and relate to different operating systems ${ }^{18}$. This twofold ability has grounded their widespread diffusion within different scientific fields and several computer environments. As far as their representative nature is concerned, ontologies do not aim to constitute an objective representation of reality, but rather a tool for its reading or critical representation; they do not coincide with conceptualisation but are a representation of it, developed through a specific language ${ }^{19}$. Ontologies' representation models are defined through a logical structure of knowledge, articulated in classes, properties and rules. The first represent concepts and constitute a whole that can encompass different entities; properties expand the description through the expression of relations between concepts. Finally, rules allow the activation of the inferential potential of ontology, that is, the possibility of developing reasoning starting from established a priori conditions between entities.

\footnotetext{
${ }_{18}$ Among the wide literature that deals with ontologies, the interested reader may find details in Gruber 1993; Guarino-Giaretta 1995; Studer-Benjamins-Fensel 1998; Doerr 2009.

19 The interpretative nature of ontologies is thoroughly argued by Fred Fonseca and James Martin (FonsecaMartin 2005).
} 
As for ontologies' ability to refer to different computer systems, this is due to the language through which they are developed, that is able to communicate within heterogeneous environments. This ability makes their application sought in many contexts, particularly where it is necessary to facilitate sharing and integration of data and information, interoperability (between different software) and aggregation of contents.

An ontology-based modelling process is divided into three main phases: the definition of the scope; the construction of the ontology; the implementation and publication of the model. The whole process requires the integrated intervention of experts in knowledge engineering and in the field concerned by the general scope. Especially, the definition of the scientific context and the construction of the ontology should necessarily be developed by scholars, who know in depth the theoretical framework of reference, to ensure the critical contribution that is required for proper modelling.

Within the outlined theoretical frame, a specific model for architectural conservation has been developed. The proposed model, called Conservation Process Model (CPM) aims to represent the semantics of architectural conservation and develop a computer tool that achieves integration, mediation and exchange of information in this field, facilitating the necessary dialectical relationship between research and design. After the first phase of the autonomous study, the research group has addressed other mature formalisations, starting from the Conceptual Reference Model of the International Committee for Documentation (CIDOC CRM) and the Functional Requirements for Bibliographic Records (FRBRoo) ${ }^{20}$, assessing consistencies and lacks and outlining appropriate integrations and adaptations. Modelling has specially focussed on conceptual issues related to the architectural design as it was only marginally attended by existing ontologies (mainly tackling museums and libraries management).

The CPM model consists of five main domains ${ }^{21}$ (Fig. 1). These are intended to develop the representation of the whole conservation process, from the description of the building ('artefact' domain), to the analysis developed for its knowledge ('historical buildings investigation process' domain), to the critical understanding of its transformations ('life cycle_1' domain) and finally to the conservation and maintaining design ('life cycle_2' domain). The fifth domain allows describing the actors involved in various ways in the existence of the building ('actors' domain).

Just to provide a quick glance at the model, we give hereby a brief description of one of the modelled domains, the 'historical buildings investigation process', dedicated to the study of the architectural work.

\footnotetext{
${ }^{20}$ Within cultural heritage field, among the various existing ontologies, the best-known and probably best-developed model is the Conceptual Reference Model for the formalisation of knowledge related to museum management, carried out by CIDOC (International Committee for documentation). It became ISO standard in 2006 (Crofts et al. 2010). Besides CIDOC CRM another authoritative model has been developed within bibliographic context, the Functional Requirements for Bibliographic Records (FRBR).

${ }^{21}$ The model has been described through two main scientific papers by the authors (Acierno et al. 2017; Simeone-Cursi-Acierno 2019)
} 


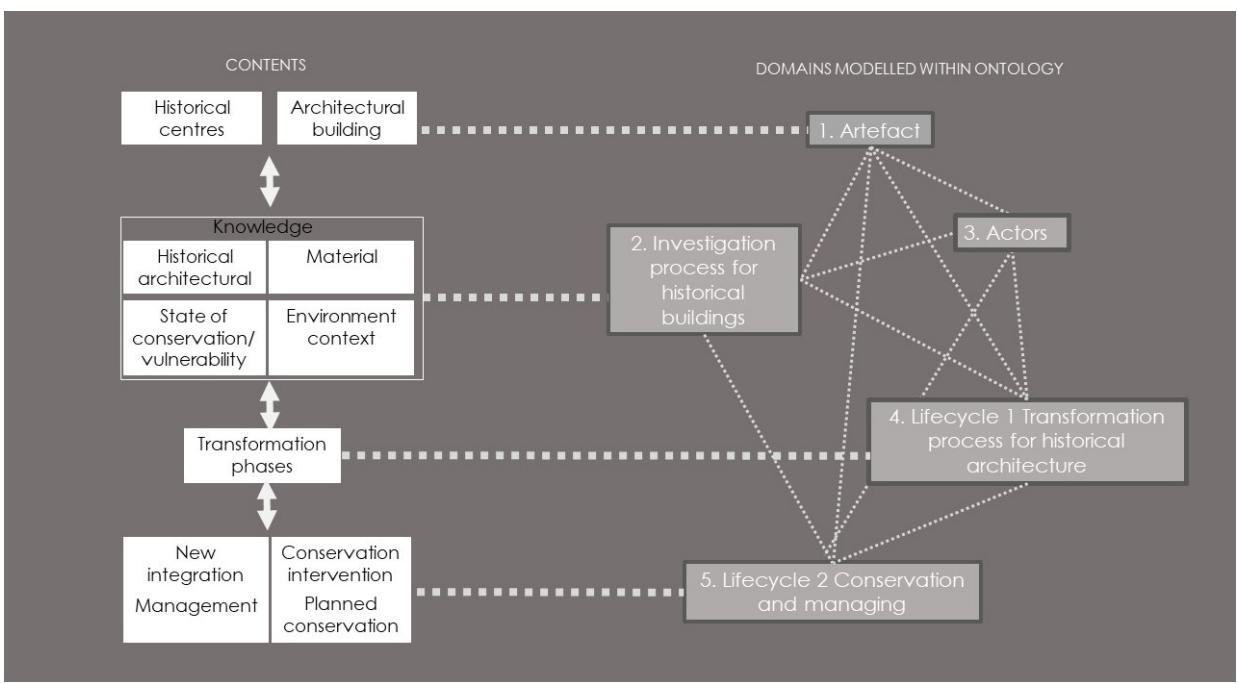

Figure 1. Schematic representation of the Conservation Process Model (CPM) structure

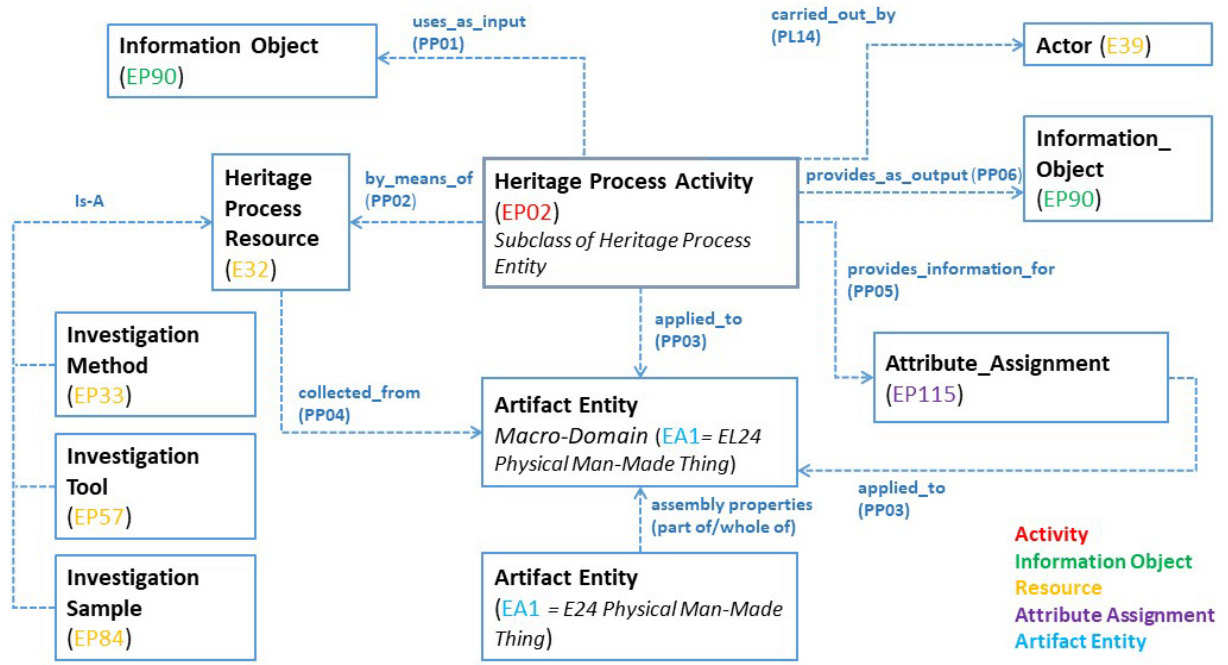

Figure 2. Schematic representation of a standard investigation activity: the boxes represent classes, the arrows represent properties

The description of investigation activity addresses two main levels: one of a descriptive nature, the other oriented to the enunciation of the results achieved (Fig. 2). As far as description is concerned, it points out not only the definition of the activity itself but also the resources required to carry it out. Resources may belong to differ- 


\begin{tabular}{|l|l|l|l|}
\hline Cod. & \multicolumn{2}{|l|}{ Name: Stratigraphic Investigation of the S. Saba Oratory } \\
\hline Class & & \multicolumn{2}{|l|}{ Stratigraphic Investigation Activity } \\
\hline Subclass of & & Heritage direct Investigation Activity \\
\hline Superclass of & & - & \multicolumn{2}{l|}{ Survey document: architectural survey } \\
\hline Object Properties & & Uses as input & Tool: Drawing, measuring instruments \\
\hline & & By means of & Actor: Conservation architect \\
\hline & & By means of & Method: Measuring \\
\hline & & & Method: Comparing \\
\hline & & & Method: Graphic representation \\
\hline & & & Artefact: Elevation structures (walls) \\
\hline & & Applied to & Information object: stratigraphic analysis \\
\hline & & Provides as output & Attribute assignment: dating \\
\hline Data properties & & Provides information for & date \\
\hline & & Carried out by & Actor: Name of the actor \\
\hline Notes & & - & \\
\hline
\end{tabular}

Figure 3. Example of formalisation form. The instance described is the masonry stratigraphic analysis; the formalising classes are in bold character

ent classes according to their nature ('actor', 'tool', 'method', 'sample' or 'external conceptual references' classes).

With regard to surveys results representation, more complex modelling was required to make it possible to account for the specificity of the investigation process preliminary to conservation design. The model has considered the difference between results providing information and results providing attributions, addressing therefore the twofold nature, both philological and hermeneutical, of the investigation process for conservation design. The first refer to data obtained through analytical processes or outlined as recognisable structure and documented as single units and are formalised through the class 'information object'22. The latter refers to statements eventually expressed grounding on a critical elaboration, such as attributions to authors or historical periods ('attribute assignment'23) or identifications ('appellation assignment'). Either 'information object' or 'attribute assignment' and 'appellation assignment' are classes imported from CIDOC CRM.

As an example, we will address two different types of surveys, stratigraphic masonry investigation and bibliographical and archival research.

${ }^{22}$ According to CIDOC CRM an Information Object is defined as: "identifiable immaterial items, such as a data sets, images, texts [...], that have an objectively recognizable structure and are documented as single units".

${ }^{23}$ According to CIDOC CRM an Attribute Assignment is defined as: "actions of making assertions about properties of an object or any relation between two items or concepts". 


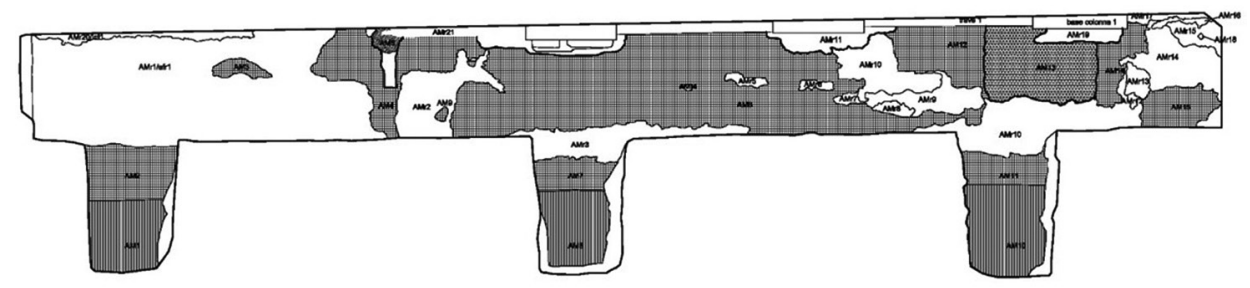

$\begin{array}{ll}\text { BUILDING ELEMENTS } & \\ \text { SIMPLE BUILDING ELEMENTS } & \text { COMPLEX BUILDING ELEMENTS } \\ \text { Brick elements } & \text { Amn masonry } \\ \mathrm{Br} \text { brick } & \mathrm{Amr} \text { plastered masonry } \\ \mathrm{St} \text { shaped tile } & \mathrm{Afr} \text { fresco plaster } \\ \text { wt whole tile } & \text { In plaster }\end{array}$

Figure 4. Schematic diagram showing the stratigraphic analysis of the northern wall of the Saint Saba Oratory, the building from which the modelling was carried out (the diagram was reworked by the author upon a drawing by S. Cutarelli).

The output of the analysis is conceived as an 'Information object'

With respect to stratigraphic analysis modelling, beyond the structural formalisation that can be well appreciated through the form of Fig. 3, what is worth examining is its twofold relation with the 'artefact' domain and 'life cycle_1' domain. The investigation results are either contributing to the building constructive features description ('artefact' domain) or the building transformation assessment ('life cycle_1' domain). From the formalising point of view the investigation result, that is to say a document that describes the identification of the different masonry types, their distribution on the elevation structures and their reciprocal position, is to be considered an information object (Fig. 4). This information object acts as an input for the artefact description and, at the same time, provides information for critical assessment, as for example, data attribution, which is formalised as an attribute assignment ${ }^{24}$. The attribution of the date actually contributes to the hypothesis of the building constructive phases, tackling therefore the 'life cycle_1' domain.

As regards archival and bibliographical investigation, the description of its results has required a further specification. Alongside the preliminary evaluation of the reliability of the scientific contribution, the identification of the sources and the type of knowledge that the bibliographic contribution is able to provide, whether documentary or critical, ought to be necessarily formalised. Moreover, whether the contribution is referring to the architectural organism - as it is today - or to individual parts of it, the specific relevance to the object will be estimated. The bibliographical research is mainly related to the artefact through the domain 'actors', which gathers

\footnotetext{
${ }^{24}$ Date attribution is generally provided by the merging of data given by the study of the 'relative chronology' (given by the stratigraphic analysis) and other information derived from a comparing activity with similar masonry types.
} 


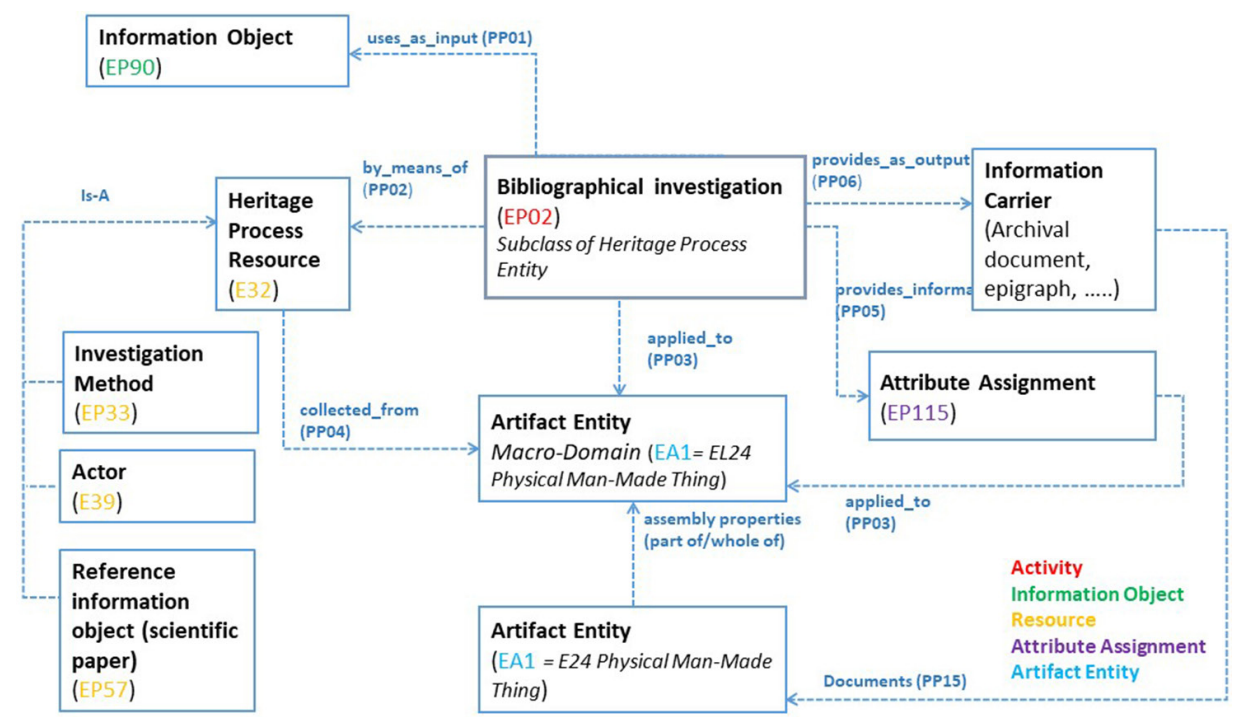

Figure 5. Schematic representation of bibliographical research formalisation

the scholars who have dealt with the object in different ways. The relationship is expressed by the property: "It is studied by" or "It is documented by". In the first case, reference is made to the historical-critical contribution of the publication; in the second case, reference is made to specific information sources such as documents, epigraphs, brick manufacturing stamps and anything else that constitutes a dating element, published in the quoted publication. Either the scientific papers or the information source are formalised as subclasses of the class 'information object', but the first is considered within the subclass 'expression work' ${ }^{25}$ whereas the latter refers to the subclass 'information carriers' ${ }^{26}$. The definitions of these classes and properties make it possible to structure a model that allows a complete representation of the state of the art: the studies carried out but also the hypotheses proposed by the various interpretations, clearly expressing the knowledge base of the object (Fig. 5). The archival research is formalised through a similar schema. The results are necessarily related to its author, as archival documents become information carriers since they are retrieved by scholars and referred to the architectural work (Fig. 6). Particularly,

${ }^{25}$ This 'class' has been formalized within FRBRoo, the model addressed to bibliographical records. The class 'Expression Work', is defined as: 'the intellectual or artistic realisations of 'works' in the form of identifiable immaterial objects, such as texts, poems [...] or any combination of such forms that have objectively recognisable structures".

${ }^{26}$ According to CIDOC CRM, the class, 'Information carrier', is defined as: "all instances of E22 ManMade Object that are explicitly designed to act as persistent physical carriers for instances of E73 Information Object". 


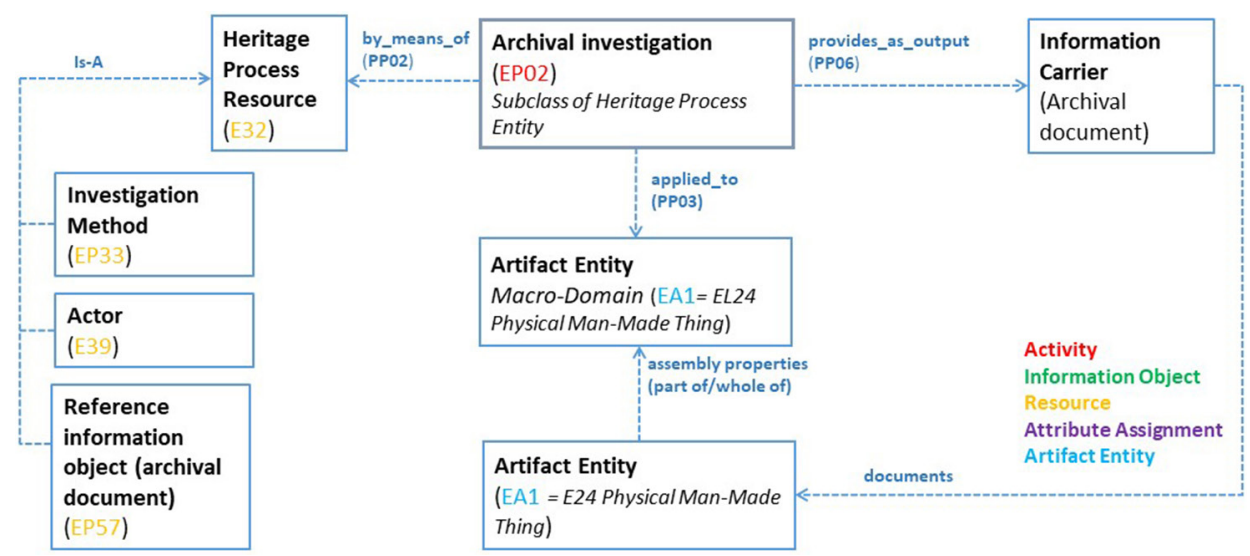

Figure 6. Schematic representation of archival research formalisation

documents are referred to as 'information carrier' formalised, as aforementioned, as a subclass of 'information object'.

Besides the possibility of representing either surveys methodology or results, the most interesting opportunity provided by modelling by means of ontologies is that the results of the individual surveys are connected between them and hopefully referable to a common critical conclusion.

The connection between them is assured by the fact that every result is referred to the building or to a part of it; therefore, the representation of the building will encompass all the information resulting from the surveys, allowing their synoptic evaluation. The comparison between the different information and the eventual alignment to a common assessment will be made possible by ontology's inferential ability. As aforementioned, this leans upon the possibility of establishing a system of reasoning rules that connects starting initial conditions to specific assessments, thereby allowing either the inference to new knowledge, or the detection of inconsistencies between different results, eventually originating from different surveys.

As a matter of fact, the research path shows the concrete attempt to defining a computer tool able to support activities aimed at the conservation of historical buildings, while respecting the discipline and its specificities. What seems particularly innovative is the approach to representation, which is reversing the traditional way of digital practice, as it does not start from the modelling of the object, but from the knowledge necessary to model it. This attitude, methodologically reflecting the operational procedure of conservation, shows an approach able to resolve, at least for a good part, the criticalities attributed to computer tools used until now. In the proposed model, the formalisation is based on conceptual categories defined a priori by the context of architectural criticism and conservation. In this way, the potential of new technologies, in terms of rigour and ability to manage complex data systems, are integrated with humanistic needs. 


\section{APPLICATION OF GIS PLATFORMS FOR CULTURAL HERITAGE IN ITALY (S.C.)}

GIS platforms, which are well-established technologies in urban planning disciplines, have also gradually established themselves since the 1990s in the field of restoration and conservation of cultural heritage; Geographic Information Systems make it possible to associate heterogeneous alphanumeric data with georeferred maps and are therefore useful for managing documentation relating to research and interventions on historical buildings. Applications carried out on an architectural, urban and territorial $\mathrm{scale}^{27}$ have demonstrated the potential of these tools, due to their ability to store and update a considerable amount of information, to examine geo-referenced elements in order to consult the content of the database and to superimpose different information layers to establish relations between the various topics. The systems applied to individual buildings and urban contexts have highlighted the opportunity to design flexible platforms that are adapted to the specific characteristics of different cases, as well as the need to standardise vocabulary and data structure in order to extend their use and exchange information. The need to order content according to a coherent, shared and methodologically well-founded approach is particularly evident for the GISs that relate to vast geographical areas and different types of assets, which involve a multitude of disciplinary and institutional skills.

The platforms of the Italian Ministry of Cultural Heritage and Activities and Tourism, which are interoperable via the 'Vincoli in Rete' ${ }^{28}$ website, are in this respect stable and meaningful references developed by organisations within the body responsible for protection activities. In particular, the cultural heritage Risk Map, designed by the Istituto Superiore per la Conservazione e il Restauro (High Institute for Conservation and Restoration), is a Territorial Information System that can be accessed online through a WebGIS system and covers the entire country ${ }^{29}$ (Fig. 7). The TIS is designed to record information on cultural heritage, to assess the risk of its loss and to guide, under normal conditions, planning of prevention measures. During the last seismic emergency in central Italy, which was declared in 2016 and is still ongoing, the platform has also been used to manage the documentation accompanying the operations to recover and relocate the movable works removed from the damaged buildings.

The risk is statistically calculated according to the territorial danger and vulnerability of the buildings. The first is related to the probability that natural or man-made phenomena of a certain magnitude occur in a given area, such as earthquakes, landslides, floods, air pollution, depopulation and tourism pressure. The indicator is taken from thematic maps and the results of statistical and environmental surveys,

${ }^{27}$ Salonia-Negri 2005; Cacace 2006; Bartolomucci 2008; Negri 2008; Bartolomucci-Bonzagni-Trizio 2012.

${ }^{28}<$ www.vincoliinrete.beniculturali.it> (Accessed 14/12/2019).

$29<$ www.cartadelrischio.beniculturali.it $>$ (Accessed 14/12/2019). Among the most recent publications see, Cacace 2015, in English, and Cacace 2019, with an overview of the specific bibliography. 


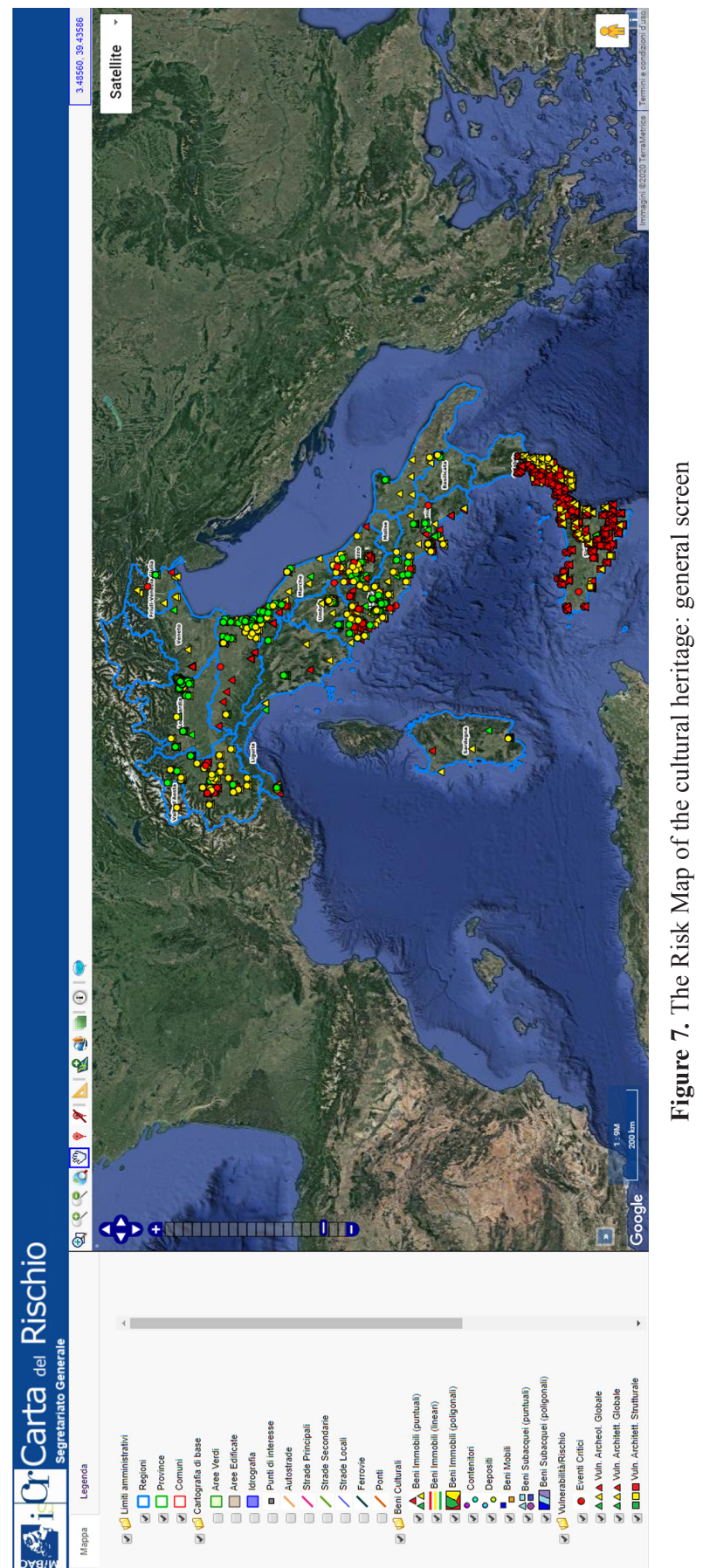




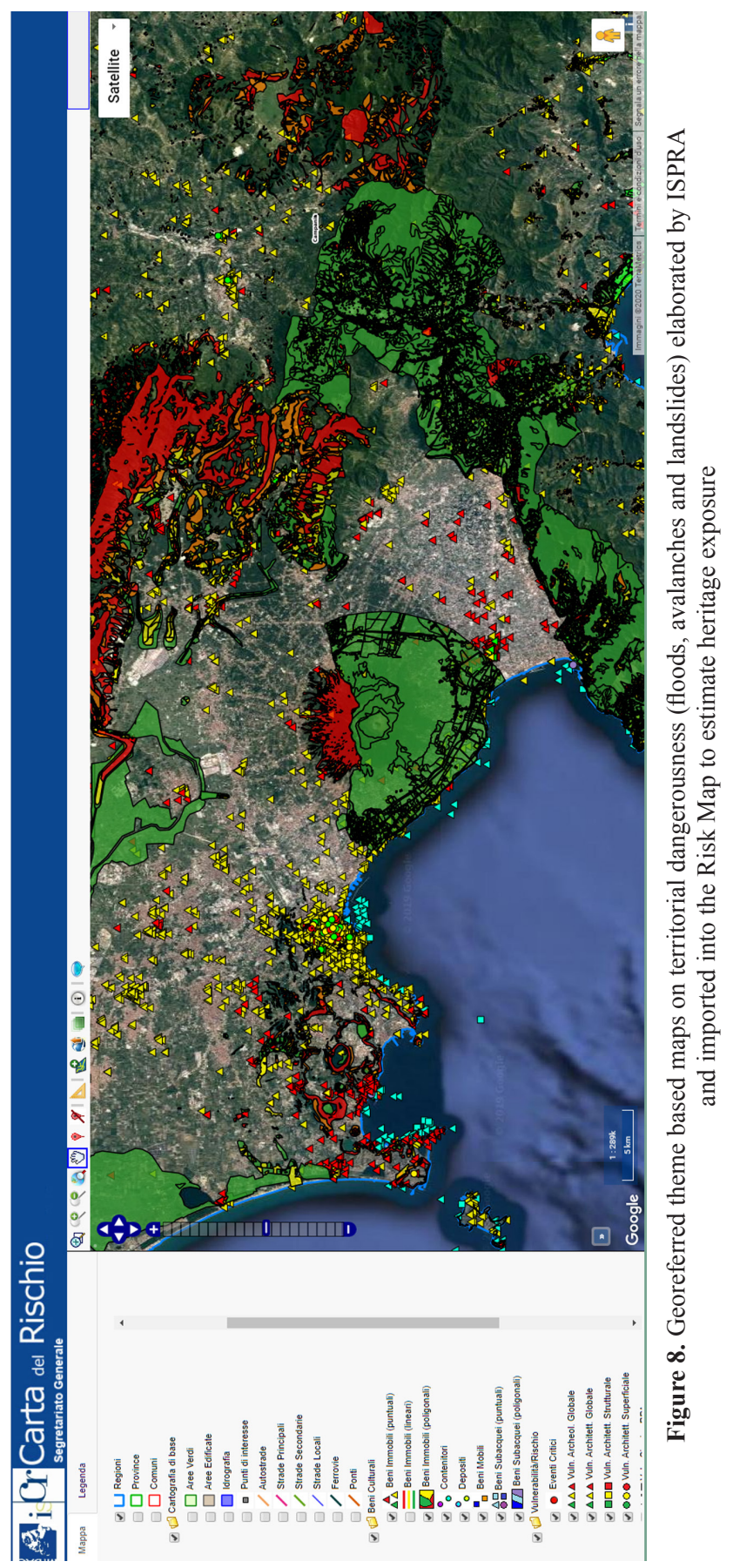




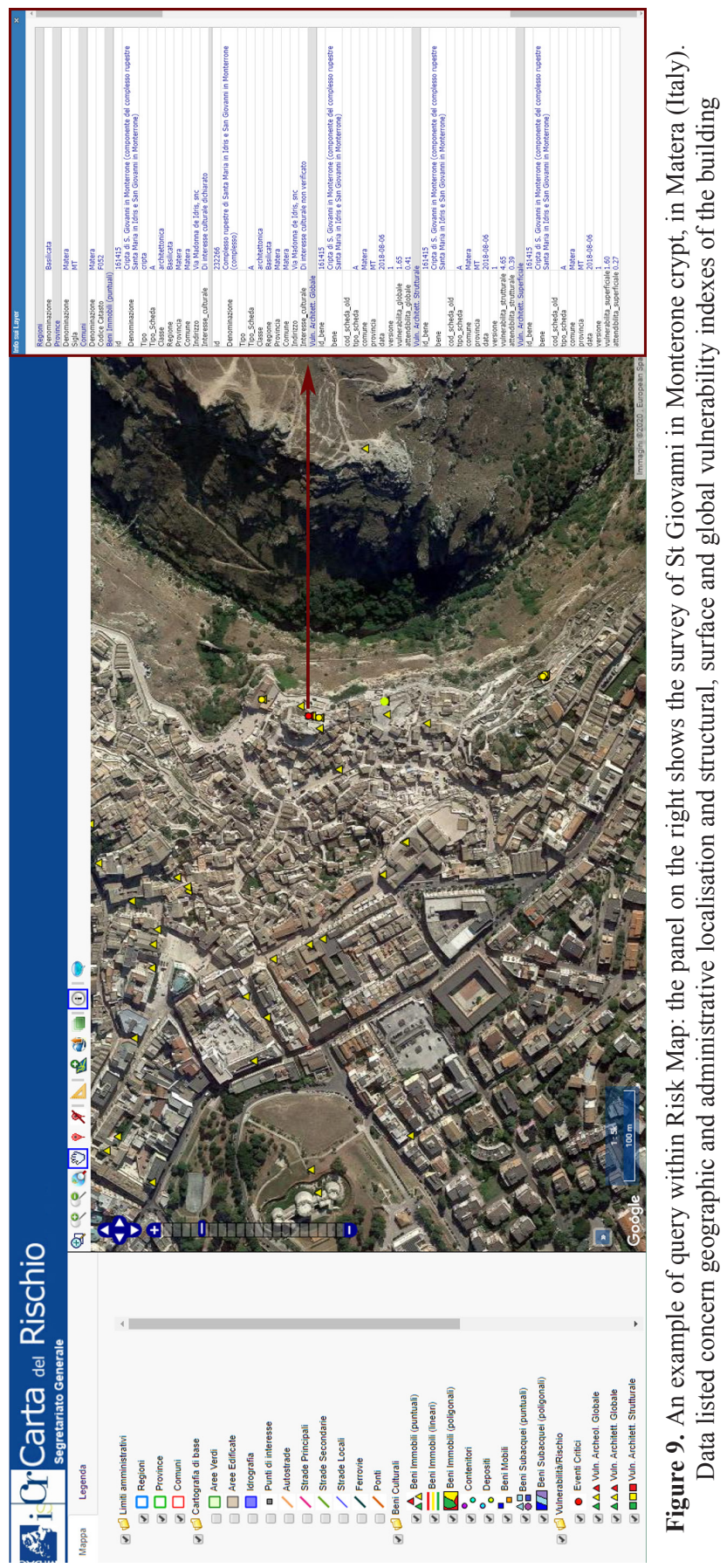


acquired by the system through the websites of various bodies ${ }^{30}$ (Fig. 8). Vulnerability, on the other hand, indicates buildings' susceptibility to damage and is therefore particularly influenced by their state of conservation. The comparison between the indices statistically calculated on the basis of numerous parameters, evaluated during expeditious surveys, makes it possible to establish operational priorities and to plan monitoring and emergency response actions (Fig. 9).

The planning approach of the Risk Map, geared towards the proper management of the conservation process, is therefore based on a preliminary cognitive stage, aimed at investigating the environmental exposure and physical structure of the historical building. Archiving of information relating to cultural heritage is entrusted to separate filing models, which refer to homogeneous asset categories and are borrowed from the cataloguing standards of the Istituto Centrale per il Catalogo e la Documentazione (Central Institute for Cataloguing and Documentation) ${ }^{31}$. At present, the TIS contains assessment forms on movable and immovable goods, referring to works of art and monuments; those relating to historical centres, on the other hand, are currently being developed ${ }^{32}$.

The form layouts of the buildings, split into architectural and archaeological categories, consist of a data section and a part dedicated to the survey of the damage, divided into two levels of detail (Fig. 10). The identifying and descriptive data of the buildings is therefore independent and can be separated from the conservation problems both in the compilation and reading of the form. Moreover, the rendering of buildings' transformation events does not take into account their construction aspects and is entrusted to a register of chronologically ordered information. In architectural heritage, interventions attributed to an architect or to a specific cultural area are also indicated, while in archaeological heritage the original function of the building, past excavations and reuse interventions are outlined. This information, generally deduced from a documentary examination, is not related to the direct survey of the buildings and does not imply any immediate relationship with the state of conservation; moreover, as already noted, in architectural heritage, the first level vulnerability assessment form has only recently been provided with references to construction techniques and materials.

The different features of buildings found in old town centres - which are often poorly documented, characterised above all by the technological components and rarely affected by interventions chronologically defined or traceable to a specific architect - suggested that the content of the most recent filing models should be calibrated differently. The set of plans relating to historical centres returns the reading

\footnotetext{
${ }^{30}$ Among these we mainly refer to Istituto Superiore per la protezione e la ricerca ambientale (ISPRA: Superior Institute for the environmental protection and research) and the Istituto nazionale di statistica (ISTAT: National Institute for statistics).

${ }^{31}$ Actually, the partial alignment of the categories of the Risk Map to those of 'SIGECweb', the information system of the Catalogue, allows the two platforms to share data through 'Vincoli in Rete', thanks to their interoperability.

${ }^{32}$ Fiorani 2019.
} 

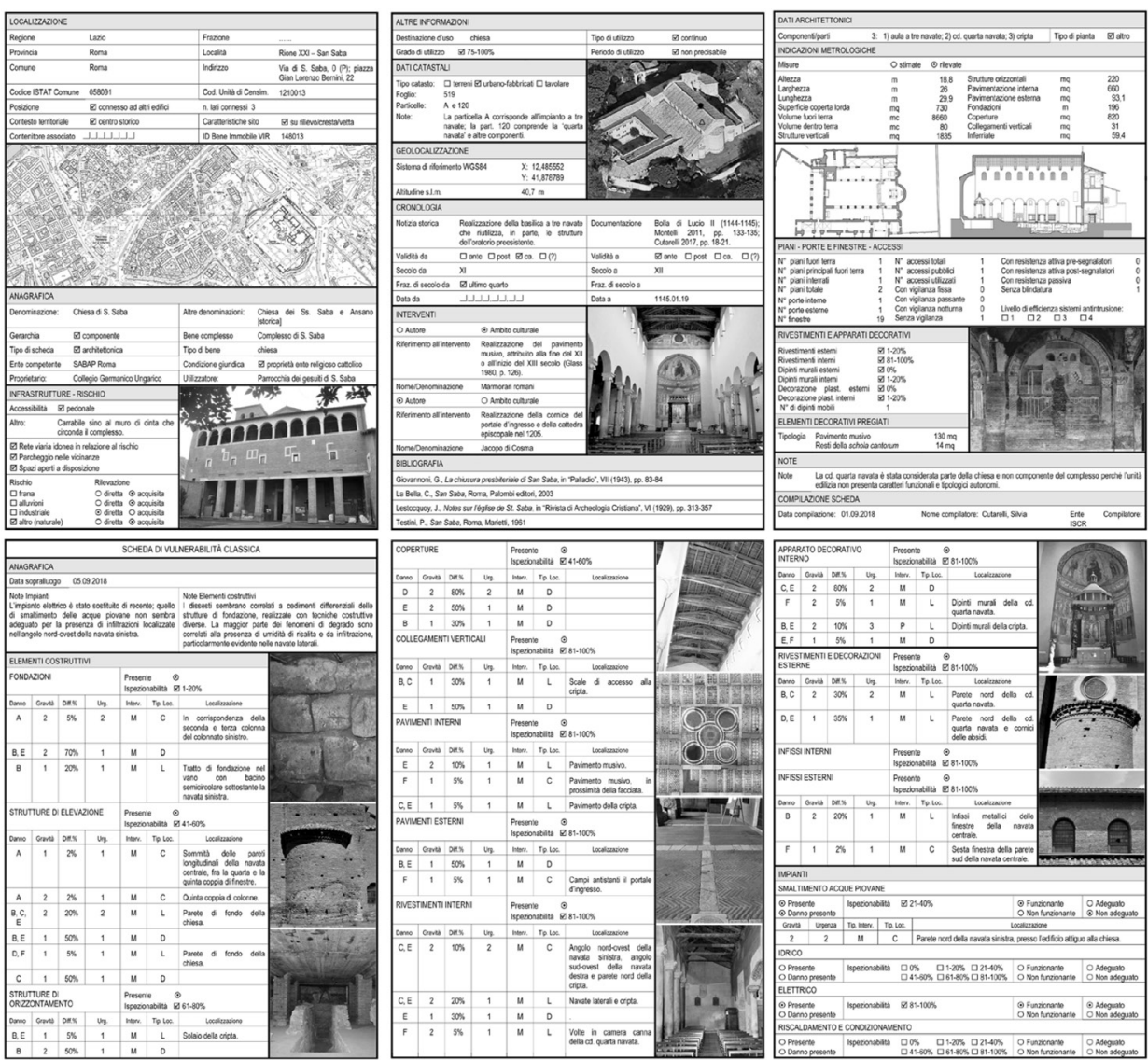

Figure 10. Architectural survey form analysing the church of St Saba in Rome (Fiorani 2019. 142-143): the identification data are recorded in the upper panels, while the definition of vulnerability is shown in the lower ones

of the buildings from the urban to the construction scale, strengthening the links between the historical, structural and conservative aspects. In the platform the 'Historical Centre', 'Urban-Aggregate Unit' and 'Specialist and Residential Punctual Urban-Building Unit' forms have been computerised; those related to 'Urban Spaces', 'Building Fronts' and 'Building Units' will be added later ${ }^{33}$.

In addition to data on the geographical-administrative and land registry location, the more general form provides brief details of a geographical, geological, demographic and socio-economic nature. It describes the urban layout through functional and morphological features, the rendering of the stages of the town's expansion, the

\footnotetext{
${ }^{33}$ Fiorani 2019. 97-162.
} 


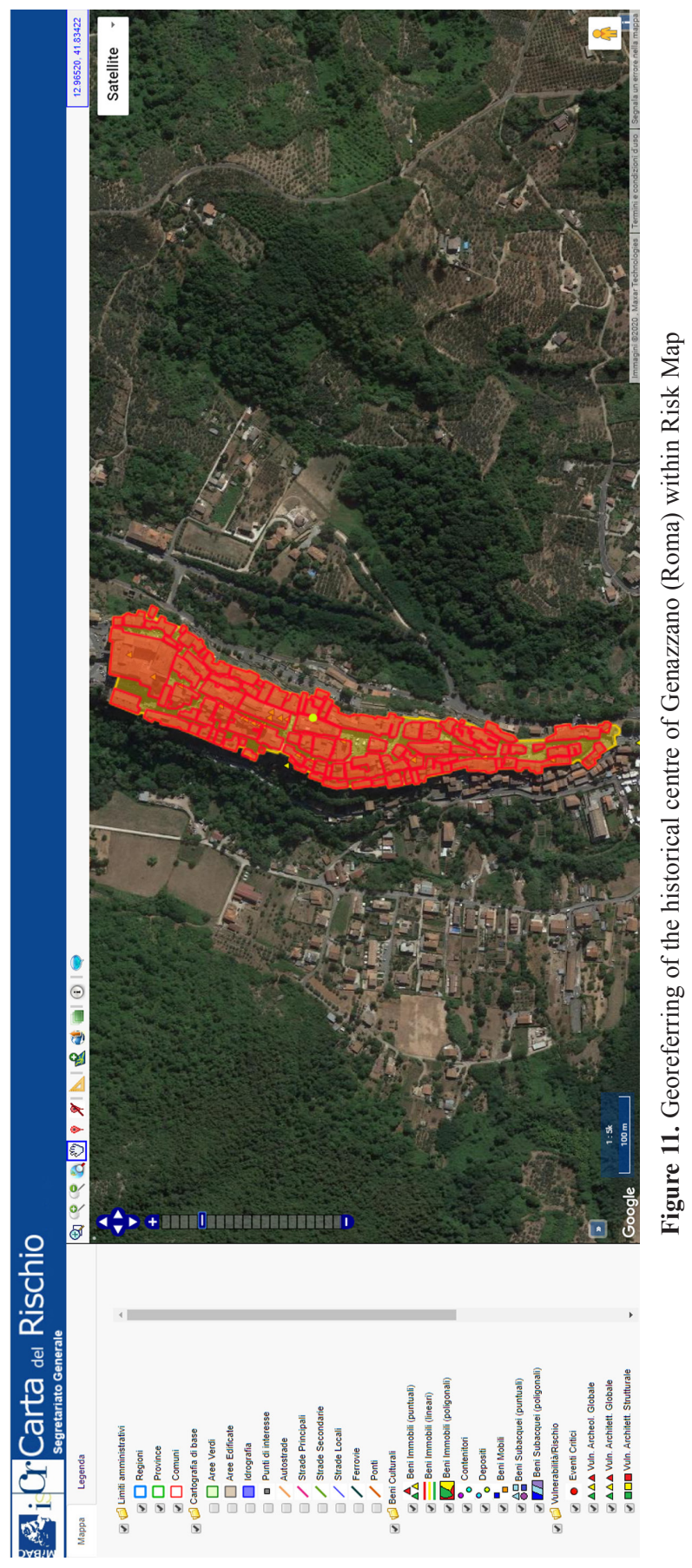




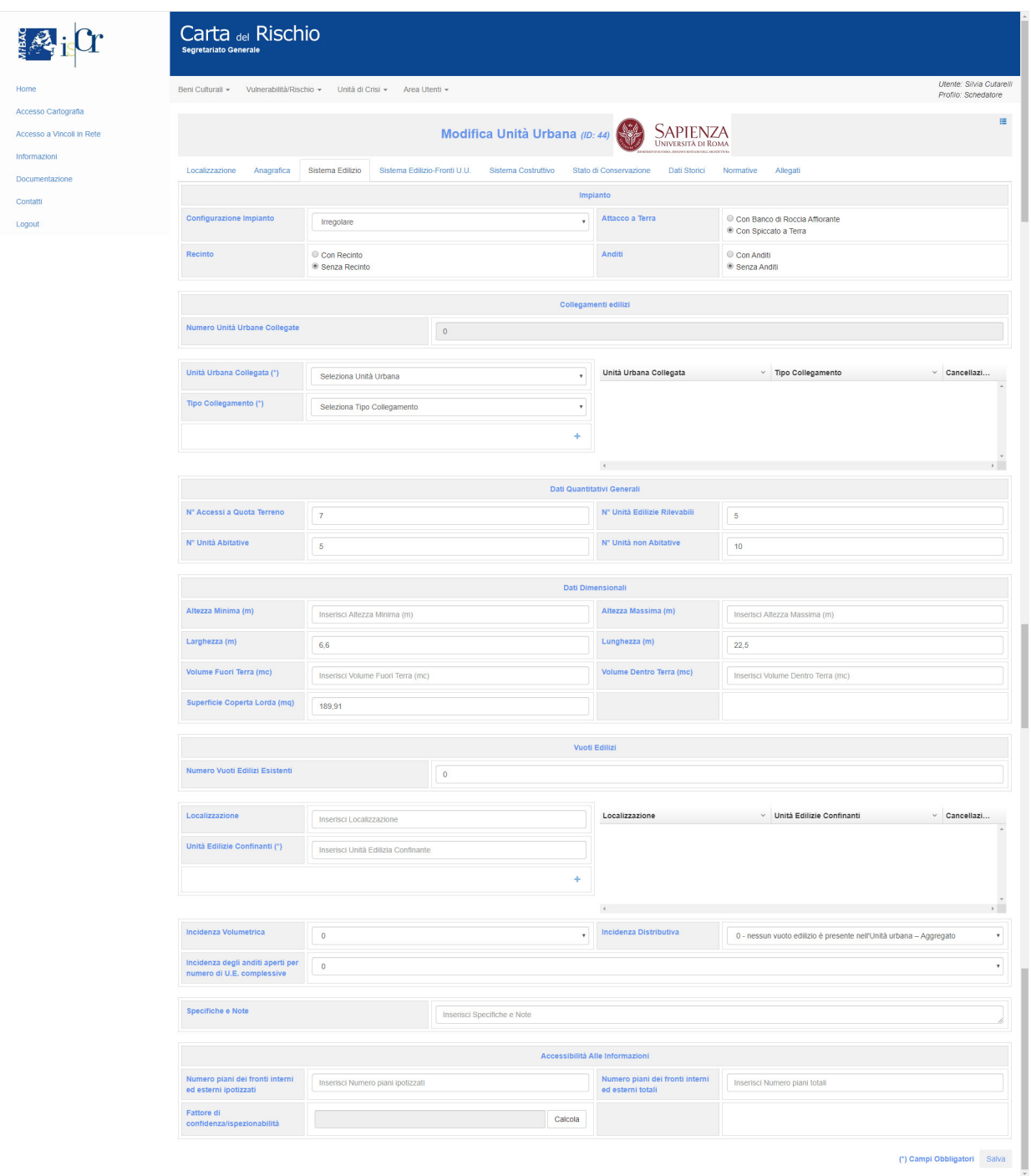

Figure 12. A section of a Risk Map forms surveying the historical centre, dealing with the Building system of an Urban Unit-Aggregate

identification of the physical and administrative divisions, the examination of the links between the town and the local area, such as the natural and artificial borders, defence system and routes. The plan also identifies the architectural and structural elements that characterise the buildings - i.e. the building types, the technological components and the most common decorative elements - and finally specifies the chronology, the sources and the relevant urban planning tools. 
The investigation is then extended to the scale of the intermediate components of the site, made up of building aggregates or, more rarely, isolated buildings. The reading of the materials - examined in the first instance on a planimetric basis to define the primitive core and subsequent extensions, the relative chronological period and the type of systems - is developed in elevation, since the 'Urban-Aggregate Unit' form proceeds from the perimeter of the blocks to the survey of the fronts, from the identification of the building units to the calculation of the external and internal levels $^{34}$. The ongoing trials in two small towns in Lazio, Cittaducale, in the province of Rieti, and Genazzano, in the province of Rome, have made it possible to validate the structure of the data, to integrate the form entries, to expand thesauruses and to recalibrate calculation algorithms ${ }^{35}$ (Fig. 11).

In addition to the toponymic and cadastral location, the form indicates the degree, type and period of use of the aggregate. It then defines the characteristics of the building system, its configuration, the presence of connections with neighbouring Urban Units, general quantitative and dimensional data, the distribution and incidence of building voids and the features of the fronts (Fig. 12). The description includes a schematic diagram of the building volumes, substantiated by the identification of the processes of addition, recasting or replacement of individual cells and the identification of the number of 'levels', intended as portions of the fronts of each unit between two floors (Fig. 13); the levels, in fact, are the reference units for calculating the incidences reported in the following sections and for assessing the reliability of the information, expressed by two confidence factors based on the total levels and levels that can be inspected or hypothesised and which feature coverings ${ }^{36}$.

The entries dedicated to the construction system and to the state of conservation show the index of transformations and changes and that of vulnerability: the first is deduced from the incidences of modern architectural components, corresponding to individual building units, building elements, elevations or superstructures, replacements, repairs, coverings and fixtures; the second is derived from the incidences of construction vulnerabilities, structural instability and degradation of surfaces and roofs. Both values contribute to defining the risk of loss, subject not only to the state of conservation but also to the degree of alteration of the historical building. They are reciprocally correlated since modern interventions can conceal degradation and instability or stratifications, but also generate construction weaknesses such as vertical juxtapositions, horizontal overlaps, discontinuities and building voids

\footnotetext{
34 The 'Specialist and Residential Punctual Urban-Building Unit' form layout shows the same setting and constitutes a simplified variation of the 'Urban-Aggregate Unit'. As a matter of fact, it considers the single Building Unit as a macroscale entity.

${ }^{35}$ Fiorani et al. 2019.

${ }^{36}$ The confidence factors, expressing the accessibility and the visibility of the fronts of the aggregate, are defined by the relationship among the supposed and total levels and by the relationship among detectable levels and levels covered by plaster or cladding.
} 

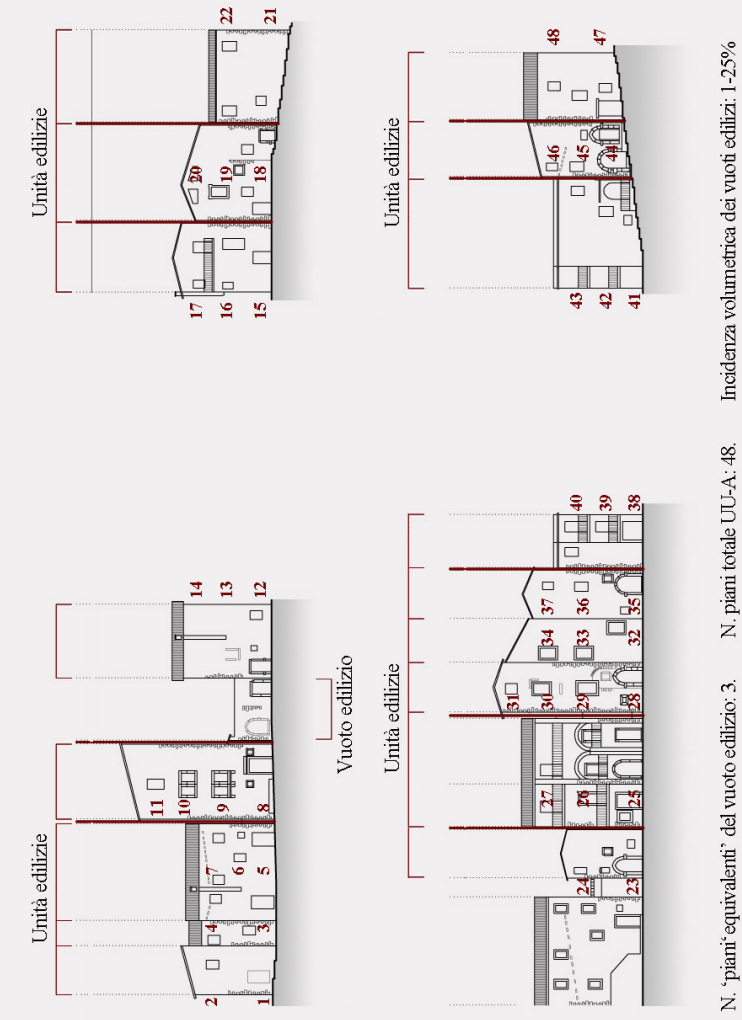

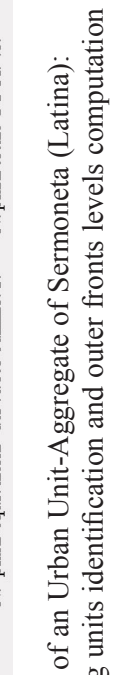
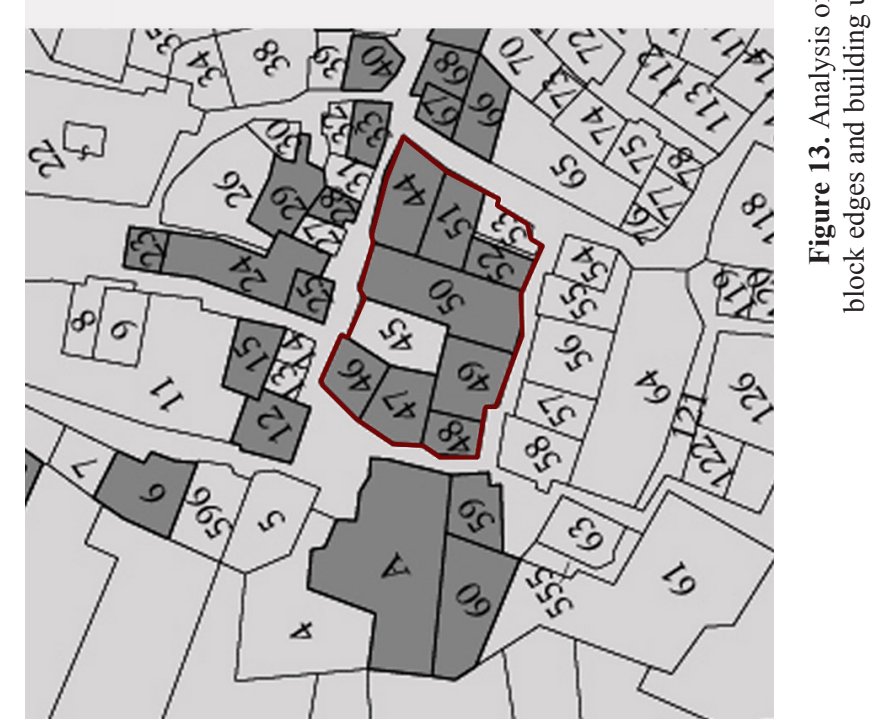

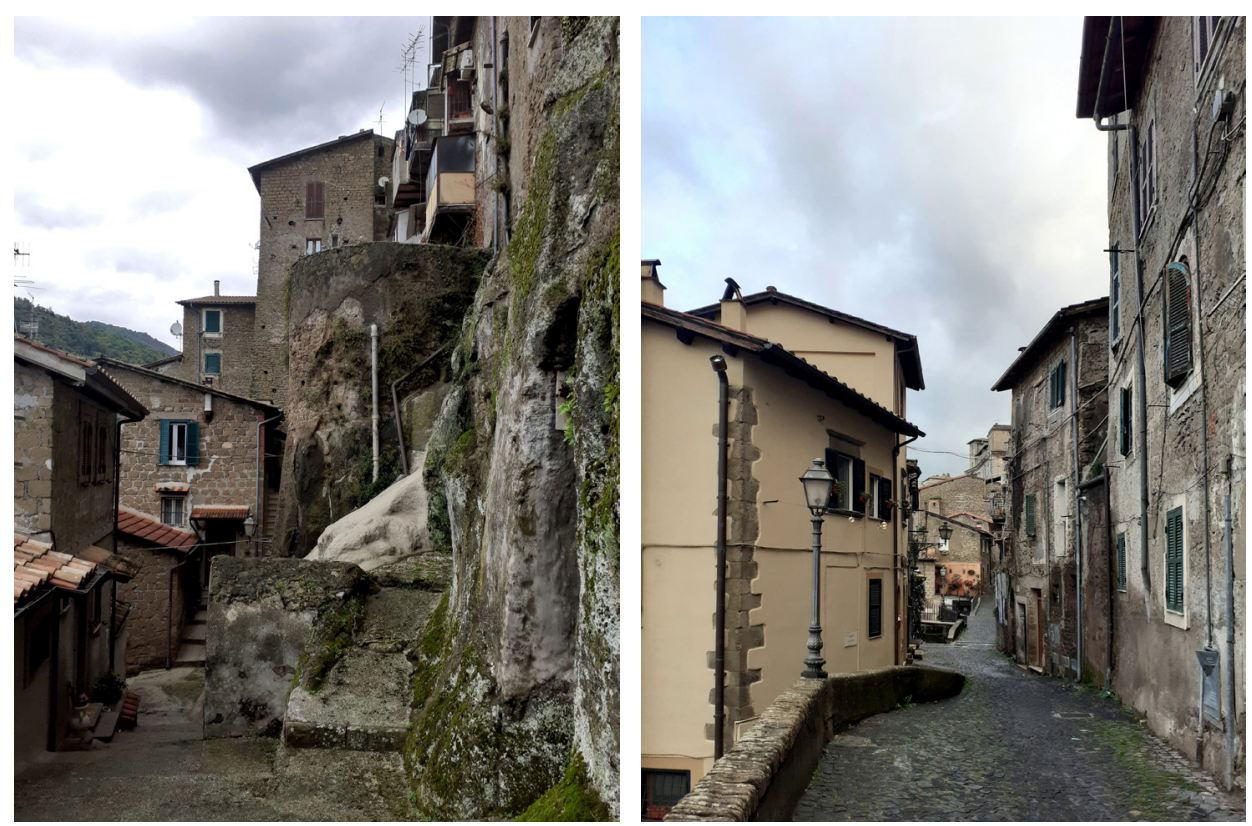

Figures 14-15. Modern transformations in the historical buildings of Genazzano (Roma). On the one hand, the replacement of coverings, hindering the direct survey of the fabrics, rather alters the perception of the state of conservation, making it falsely good. On the other hand, the addition of balconies, revealing horizontal overlapping among different building systems, worsens the index of vulnerability

(Figs. 14-15). The results provided by applications to concrete cases will soon make it possible to analytically assess the dual influence of modern transformations on the state of conservation.

The intrinsic rigidity of the form layouts often involves a representation that is abstract or insufficiently adapted to the complexity of the existent; in the Risk Map models relating to historical centres, an attempt has been made to preserve the degree of flexibility required by the unique nature of each case through the insertion of open fields, which make it possible to implement the thesaurus entries and to add further specifications to each section. The methodology followed in the drafting of the forms is in line with traditional investigative methods, since the investigation encompasses the morphological description of the building, the macroscopic identification of historical construction elements and recent transformations, and the definition of the state of conservation. The distinction between historical and modern components of transformation provides a concise reading of the building stratifications, which appears to be consistent with the expedient criteria of the survey, but can nonetheless be interpreted in different ways. In fact, it is linked not so much to chronological criteria but to evaluations of a historical and structural nature, relating to the materi- 
al and figurative compatibility of the building elements. Data fine-tuning is assigned to the forms designed for the building scale, following an interscalar approach that involves successive degrees of analysis.

\section{OBSERVATIONS REGARDING CERTAIN ALGORITHMS FOR MANAGING CULTURAL HERITAGE (A.D.)}

The word algorithm refers to any scheme or systematic process of calculation; in the field of computing, in particular, it refers to a finite sequence of elementary operations that can easily be performed by a computer which, from one set of input data, produces another set of output data that meets preassigned requirements. This definition sums up the fundamental properties of an algorithm: "effectiveness", namely the ability of the user to recognise and therefore carry out the instructions that constitute the algorithmic formula; "finiteness of expression", i.e. organisation according to a possibly long, but nevertheless finite sequence of operations; "finiteness of calculation", which refers to the development of a procedure within a predefined domain; "determinism", which establishes a single operation to be performed at each step of the calculation sequence ${ }^{37}$.

The application of an algorithm, moreover, requires the field in which it operates to be as homogeneous as possible, i.e. made up of components that are comparable to each other. In this sense, the use of algorithms in the management of cultural heritage, given its heterogeneity, presents obvious complexities, in particular regarding the definition of a unit of measurement that makes it possible to unequivocally quantify the heritage as a whole.

In a general risk analysis, for example, each element is assigned a value, which appears to be defined in economic terms or as a unit related to each of the risk elements (e.g. number of people, buildings, exposed areas), a condition which cannot always be adopted when working in the field of cultural heritage, since it favours the quantitative aspect. It is therefore more appropriate to characterise each asset through the evaluation of a series of parameters that can be instead related to artistic, construction and material aspects, state of conservation, etc., which, by their very nature, are difficult to quantify.

From this perspective, the cultural heritage risk models are expressed "through a scheme (which can be logically and mathematically formalised) that connects 'Risk' and 'Risk Factors' [...] based on a statistical approach" 38 .

The management of cultural heritage has long involved the use of computer systems and therefore of algorithmic formulas capable of processing data - opportunely

\footnotetext{
${ }^{37}$ See item 'algorithm' in <http://www.treccani.it/enciclopedia/algoritmo> (Accessed 13/12/2019). It is clear that while the first property is indispensable, the other "can be made less convincing or totally abandoned, producing concepts more general than that of algorithm. Most of all, renouncing the condition 'determinism' guides to the concept of not deterministic algorithm".

${ }^{38}$ Coppi 1997. 33. The inverted commas are by the author.
} 
collected in bank systems that can be consulted and updated over time - relating to all monumental heritage, to the physical-chemical and social phenomena that influence the assets' degradation process, as well as to information on their state of conservation ${ }^{39}$.

The cultural heritage Risk Map system, for example, aims to determine, through a statistical analysis model, situations of actual risk associated with each asset, appropriately cross-referencing data on territorial danger with data on the vulnerability of cultural assets, which in turn is extracted from specially drafted form layouts.

The statistical approach is therefore involved in the assessment of vulnerability, i.e. in correlating the different information recorded for each asset through 'simple' (e.g. arithmetic averages) or more 'complex' (weighted averages) algorithms. Thanks to the contribution of statistics, it is possible to establish correlations between the various thematic information, leading to the identification of the relationships between cultural heritage, state of conservation and factors at the origin of the deterioration, making it possible to define classifications relating to the risk of losing the goods ${ }^{40}$.

In order to satisfy the requirement of an expeditious survey and also the already mentioned properties relevant to a correct algorithmic formulation, the descriptive data of the analysed assets have been carefully examined in the form layouts of the Risk Map, selecting those able to identify the main characteristics and significant factors that express the state of conservation. Accordingly, the vulnerability and dangerousness indicators are divided into three 'domains' ("Structural-Static"; "Environment-Air"; "Anthropic"), which correspond to different form layouts from which the basic variables for calculating vulnerability indexes can be derived. For the first two domains, for example, vulnerability (referred to as 'classic') is calculated through a linear combination of variables that express the state of conservation of the different architectural components into which a given building unit is divided. Each variable that effectively corresponds to a judgement on the state of conservation, as well as being properly quantified through the assignment of a score, is also multiplied by a 'weight', which makes it possible, on the one hand, to make different information comparable and, on the other hand, to establish representative relationships of real conditions through weighting ${ }^{41}$.

Therefore, with respect to the complexities discussed at the start, in order to try to deal with the heterogeneous features that characterise the field of cultural heritage, the methodology developed by the Risk Map involves separate filing for archaeological goods, architectural goods, containers of goods, movable goods and historical

\footnotetext{
${ }^{39}$ Bartolomucci 2008; Bartolomucci 2009; Della Torre 2014; Negri 2008.

${ }^{40}$ See for instance, in Ferroni-Cacace 2004, the description of the evaluation model of archaeological vulnerability.

${ }^{41}$ This method, named 'Analysis in main components of ordinal variable', is applied through the technique 'PRINCALS' (Coppi 1997. 35).
} 
centres $^{42}$. Moreover, for the seismic risk assessment of listed buildings, the form layouts provided for in the Risk Map is differentiated into three architectural and construction typologies that take into account the prevalence of certain structural behaviours in seismic areas: the 'villas-apartment buildings-houses' typology covers buildings that are usually organised by levels and presumably manifest a general behaviour; the 'towers-bell towers' typology covers buildings whose seismic behaviour mainly depends on the slimness factor; the 'churches-theatres-complex building systems' typology concerns all structures that are mainly characterised by large halls without horizontal partitions and generally featured by local behaviour under earthquake, namely behaviour that can be associated with "macroelements" ${ }^{43}$. The algorithm used to assess vulnerability and seismic risk seeks to determine ranges of severity (high, medium or low), with the aim of identifying buildings that have a risk that requires priority attention (high risk), those whose examination can be left to a later time (low risk) and those that require further investigation (medium risk) ${ }^{44}$. In line with this approach, and once the relationship of risk with dangerousness, vulnerability and exposure are known, three dangerousness bands are defined, in keeping with the values proposed by the standards for Italian national seismic zones ${ }^{45}$, together with three exposure bands, based on crowding and the presence of observed valuable elements. The three vulnerability ranges are determined, in this case, with an algorithmic sequence structured to identify damage situations (such as those due to overturned walls, out of plumb, perpendicular detachments from the wall surface and shear mechanisms, combined compressive and bending stress on the wall plane) and certain structural deficiencies in the event of an earthquake (such as the lack of connections, the presence of projecting arches and vaults or the absence of earthquake-proof structures), the existence of which, even in a single section of the building under investigation, results in significant local vulnerabilities ${ }^{46}$. Unlike, therefore, the formulas adopted for 'classic' vulnerability (assessed as a linear combination of variables, each expressing a state of conservation) for seismic vulnerability, the presence of an observed or foreseeable damage situation is sufficient to make the building fragile in relation to a telluric event.

Another Italian experience that involved the use of a statistical model as a tool to expeditiously determine the seismic vulnerability of churches was conducted immediately after the 1997 earthquake in Umbria and Marche (26 September) by the

\footnotetext{
${ }^{42}$ Cacace 2006. Specifically, the use of the Risk Map for the historical centres was recently experimented: see Fiorani 2019.

${ }^{43}$ Angeletti et al. 2009. 2.

${ }^{44}$ Donatelli 2010.

${ }^{45}$ Values of dangerousness are established considering the range of 'pga', peak ground acceleration, namely the maximum acceleration of the soil produced by the earthquake and recorded by the accelerometers. High dangerousness corresponds to values of pga $>0.25 \mathrm{~g}$ or $0.25 \mathrm{~g} \geq \mathrm{pga}>0.15 \mathrm{~g}$ and high amplification in high frequencies; low dangerousness is related to values of pga $\leq 0.15 \mathrm{~g}$ (Angeletti et al. 2009. 3).

${ }^{46}$ Description of damage and conditions that may influence the structural behaviour of buildings in seismic zones is organised using 'levels' for palaces, 'sectors' for towers and 'parts' for churches. The aim is the identification of the condition of local vulnerability.
} 
Gruppo Nazionale per la Difesa dai Terremoti (National Earthquake Defence Group) and the Servizio Sismico Nazionale (National Seismic Service). The methodology, implemented in emergency post-seismic conditions, aims to quickly detect vulnerability and damage indexes, correlating a number of 'indicators' that represent weaknesses and instability observed in religious buildings affected by the earthquake ${ }^{47}$. In this case, the algorithm used consists of a weighted average of the sum of the damage mechanisms activated or that can be activated among the 28 possible damage mechanisms in the event of an earthquake ${ }^{48}$ (each of which is assigned an importance factor) from which the relevant controls considered effective are subtracted ${ }^{49}$.

Both for 'classic' and seismic vulnerability, the algorithmic formulas are independently based on historical and structural knowledge of the building in order to allow an expeditious screening in the area. All the form layouts, however, include a field for collecting, in the form of attached files, the chronology of the building under investigation, the relative bibliographic, archival and cartographic documentation, and historical photos. In particular, the seismic assessment form requires a record of the sequence of earthquakes that in the course of history have affected the town where the building is located, as well as of the history of the building in relation to significant seismic events that have affected it. The progressive archiving of this data allows those who fill in the forms to better discern both the state of conservation of historical surfaces and materials and certain conditions of structural instability (observed or foreseeable). For example, the compilation of a seismic report for a multi-storey building, characterised by a structured plan with no visible surfaces, becomes simpler and more reliable if documents attesting to certain transformations have been archived in the platform, which makes it easier to distinguish the preexisting parts from the added parts and to assess the effectiveness of the mutual connections in the event of an earthquake. The historical and structural analysis that can be developed over time and that is properly stored in the platform therefore makes it possible, on the one hand, to refine the choice of certain indicators (perfecting the result of the algorithm) and, on the other hand, to draw up an updated form based on the new knowledge acquired. The historical and structural data, in this case, is therefore not processed in the system but is offered to the technician as material to be critically associated in an 'analogue' way to the other information provided by the platform.

In order to evaluate the modern transformations and fragility of the Urban Units that populate the historical centres, always within the framework of the Risk Map,

\footnotetext{
${ }^{47}$ See Lagomarsino-Podestà 1999. This form layout has been implemented after the earthquake of Molise in 2002 (Cifani-Lemme-Podestà 2005. 116-119).

${ }^{48}$ These mechanisms, schematised in an abacus, derive from the post seismic observations aroused after the numerous earthquake in the Italian territory, since that in Friuli in 1976. (Doglioni-Moretti-Petrini 1994).

${ }^{49}$ This methodology has been adopted by the Guide Lines for the evaluation and reduction of seismic risk of the cultural heritage (Linee Guida 2010) for the evaluation at the territorial scale of the vulnerability of the churches (Evaluation level 1, 'LV1'). (Linee Guida 2010. 79-87). See also Lagomarsino et al. 2004; De Matteis-Criber-Brando 2016.
} 
an attempt has been made to guarantee a more structured interaction between this different information, introducing algorithmic formulas that can capture, in a timely manner, modern changes in finishes and construction components, material and construction defects, structural instability and degradation of surfaces and roofs. The joint evaluation of two overall indexes, one of which expresses modern transformations and changes and the other vulnerability, makes it possible, in this case, to quantitatively illustrate, together with the observed defects and fragilities, the degree of knowledge acquired with respect to the construction history of the aggregate, both in the case of an expeditious survey and in the presence of in-depth historical analysis. These two indexes are obtained by means of weighted averages among six thematic sub-indexes (respectively Changes and Modifications of Finishes; Construction Transformations and Modifications; Construction Vulnerabilities; Structural Instability and Changes; Surface Degradation; Roof Degradation), which in turn are mainly calculated with arithmetic averages. The variables that contribute to the calculation of the sub-indexes come from dedicated form layouts, in which they are expressed in the form of ranges of incidences that indicate the observed percentage of their presence; each of these ranges is then assigned a score. The 'weighting' of the sub-indexes for the calculation of the two overall indicators has been set taking into account the level of incidence: the thematic sub-index which, starting from the compilation of the form, has the greatest impact is the one that has the highest weight and the others, subsequently, contribute in a decreasing way proportional to their respective relevance.

The first applications of the 'Urban Units' form in the historical centres in Lazio, Cittaducale (Rieti) and Genazzano (Rome) have also suggested the introduction of two confidence factors into the algorithmic formulas: 'Confidence/inspectionability factor' and 'Confidence/visibility factor', which, calibrated on the percentage of frontal planes that are actually inspectable and/or visible, will be multiplied by the thematic sub-indexes that relate to the different sections of the form, reshaping the final ranking of global transformation and vulnerability indexes in view of the accessibility of information ${ }^{50}$.

With regard to this expedient, which makes it concretely possible to take into account the level of reliability of the data collected, the historical knowledge of the urban aggregate investigated plays a significant role. The acquisition, for example, from historical documentation (maps, photographs, surveys) of fronts that were not accessible at the time of a specific filing survey at least makes it possible to correctly record the presence of levels and a relative count of those hypothesised. With updated photos and/or surveys, which allow the measurement of the indicators required by the form, it is also possible to calculate the levels among those that are 'certain', making the values of the global transformation and vulnerability indexes more realistic.

\footnotetext{
${ }^{50}$ Fiorani et al. 2019.
} 
Finally, a proposal is currently being studied to introduce other weight systems into the structure of the algorithms (developed in a way that they can always be modified, without altering the calculation software) capable of grasping - in a differentiated manner - the levels of modern transformations and vulnerability according to the purpose of the filing of historical centres. If, for example, the filing evaluation of 'Urban Units' is required to assess vulnerability in anticipation of seismic events or landslides, it would make sense to prioritise indicators that affect the structural behaviour of aggregates, such as 'Construction Transformations and Changes', 'Construction Vulnerabilities' and 'Structural Instability and Modifications'. If the purpose of filing is instead to consider the state of conservation of the finishes, it makes more sense to refer to a weight system in which the 'Changes and Modifications of Finishes' and 'Degradation of Surfaces' sub-indexes have a greater bearing than all the others ${ }^{51}$.

\section{BIBLIOGRAPHY}

Acierno et al. 2017

Adamo-Gregory 2000

Angeletti et al. 2009

Bartolomucci 2008

Bartolomucci 2009

Borillo 1984

\footnotetext{
${ }^{51}$ Donatelli 2019; Fiorani et al. 2019.
}

Marta Acierno - Stefano Cursi - Donatella Fiorani - Davide Simeone: Architectural Heritage Knowledge Modelling: an Ontology-Based Framework for Conservation Process. Journal of Cultural Heritage (2017) 24C. 124-133.

Giovanni Adamo - Tullio Gregory: Informatica Umanistica. In: Enciclopedia Italiana, VI Appendice, 2000. Available at $<\mathrm{http}: / /$ www.treccani.it/enciclopedia/informatica-umanistica_(Enciclopedia-Italiana) $/>$ (Accessed 27 December 2019).

Paolo Angeletti - Alessandro Bianchi - Carlo Cacace - Adalgisa Donatelli - Omar Ceistllini - Enrica Rasimelli: Un metodo speditivo di valutazione della vulnerabilità e del rischio sismico di beni culturali. Caso di studio: Sicilia e Calabria. In Atti del XIII convegno ANIDIS (Bologna, 28 giugno - 2 luglio), 2009, sessione 4.1, pubblicazione cdrom

Carla Bartolomucci: Nuovi metodi per la documentazione. In: G. Carbonara (ed): Trattato di restauro architettonico. Grandi temi di restauro. Secondo aggiornamento, vol. X. UTET Scienze Tecniche, Milano 2008. 105-140.

Carla Bartolomucci: Documentazione informatica. In: D. Fiorani (ed): Restauro e tecnologie in architettura. Carocci, Roma 2009. 98-109.

Bartolomucci-Bonzagni-Trizio 2012 Carla Bartolomucci - Daniele Bonzagni - Ilaria Trizio: Restauro e valorizzazione dei centri storici dopo il sisma del 2009: un GIS 3D per il progetto di reintegrazione delle lacune urbane. In: $16 a$ Conferenza Nazionale ASITA, Atti (Fiera di Vicenza, 6-9 novembre 2012). S.1., s.n., 2012. 159-166.

Mario Borillo: Informatique pour les sciences de l'homme. Limites de la formalisation du raisonnement. Pierre Mardaga Editeur, Bruxelles 1984. 
Cacace 2006

Cacace 2015

Cacace 2019

Celentano-Cortesi 2004

Cifani-Lemme-Podestà 2005

Coppi 1997

Crofts et al. 2010

Della Torre 2014

De Matteis-Criber-Brando 2016

Doerr 2009

Doglioni-Moretti-Petrini 1994

Donatelli 2010

Donatelli 2019

Drucker et al. 2015
Carlo Cacace: GIS: uno strumento per la rappresentazione organizzata delle informazioni sui processi di restauro e conservazione. Bollettino ICR n.s. 13 (2006) 19-26.

Carlo Cacace: Risk Map of Cultural Heritage. In: N. Berlucchi D. Fiorani - A. Grilletto - S. Kulikov - O. Pyatkina - T. Vyatchanina (eds): Scuola di Restauro. Heritage Conservation in Italy and Russia. Nardini, Firenze 2015. 287-296.

Carlo Cacace: La Carta del Rischio per il patrimonio culturale. In: Fiorani 2019. 65-74.

Augusto Celentano - Agostino Cortesi - Paolo Mastandrea: Informatica Umanistica: una disciplina di confine. Mondo Digitale 4 (dicembre 2004) 44-55. Available at <https://web.archive.org/ web/20060506153023/http:/www.mondodigitale.net/Rivista/05_ numero_uno/Celentano_def.p._44-55.pdf $>$ (Accessed 11 December 2019).

Giandomenico Cifani - Alberto Lemme - Stefano Podestà (eds): Beni monumentali e terremoto. Dall'emergenza alla ricostruzione. Dei, Roma 2005.

Renato Coppi: Metodologia per la costruzione di modelli di rischio del patrimonio culturale. In: G. Castelli (ed): La Carta del Rischio del Patrimonio Culturale. ICR - Bonifica, Roma 1997. 33-37.

Nick Crofts - Martin Doerr - Tony Gill - Stephen Stead Matthew Stiff: Definition of the CIDOC Conceptual Reference Model, ICOM/CIDOC. Documentation Standards Group eCIDOC CRM Special Interest Group, 2010. Available at $<\mathrm{http}: / /$ www.cidoc-crm.org/sites/default/files/CIDOC\%20CRM_v6.2.7 Definition_esIP.pdf $>$ (Accessed 9 January 2020)

Stefano Della Torre (ed): ICT per il miglioramento del processo conservativo, proceedings of the International Conference, Preventive and Planned Conservation (Monza, Mantova, 5-9 maggio 2014), Vol V. Nardini, Milano 2014.

Gianfranco De Matteis - Emanuela Criber - Giuseppe Brando: Damage Probability Matrices for Three-Nave Masonry Churches in Abruzzi after the 2009 L'Aquila Earthquake. International Journal of Architectural Heritage 10 (2016) 2-3. 120-145.

Martin Doerr: Ontologies for cultural heritage. In: Steffen Staab V Rudi Studer (eds.): Hand-Book on Ontologies. Springer, Berlin Heidelberg 2009. 463-486.

Francesco Doglioni - Alberto Moretti - Vincenzo Petrini (eds): Le chiese e il terremoto. Lint, Trieste 1994.

Adalgisa Donatelli: Terremoto e architettura storica: prevenire l'emergenza. Gangemi, Roma 2010. 193-214.

Adalgisa Donatelli: Addenda: considerazioni per la definizione degli algoritmi per le schede di Unità Urbana. In: Fiorani 2019. 135-138.

Johanna Drucker - Anne Helmreich - Matthew Lincoln Francesca Rose: Digital Art History: the American Scene. Perspective. Actualité en Histoire de l'Art (2015) 2. Available at $<$ https://journals.openedition.org/perspective/6021> (Accessed 28 December 2019) 
Ferroni-Cacace 2004

Fiorani 2014

Fiorani 2019

Fiorani-Acierno 2017

Fiorani-Acierno 2019

Fiorani et al. 2019

Fonseca-Martin 2005

FRBR 1998

Gruber 1993

Guarino-Giaretta 1995

Hajnóczi 1956

Lagomarsino-Podestà 1999
Angela Ferroni - Carlo Cacace: Carta del Rischio: la vulnerabilità archeologica. In: Apparati Musivi Antichi nell'area del Mediterraneo, atti del convegno internazionale di studi (Piazza Armerina, 9-13 aprile 2003), Quaderni di Palazzo Montalbo n. 4, Dario Flaccovio, Palermo 2004. 466-472.

Donatella Fiorani: Materiale/immateriale: frontiere del restauro. Materiali e Strutture. Problemi di conservazione n.s. 3 (2014) 5-6. 9-23.

Donatella Fiorani: Il futuro dei centri storici. Digitalizzazione e strategia conservativa. Quasar, Roma 2019.

Donatella Fiorani - Marta Acierno: Conservation Process Model (cpm): A Twofold Scientific Research Scope in the Information Modelling for Cultural Heritage. In: GEOMATICS \& RESTORATION - Conservation of Cultural Heritage in the Digital Era (Florence, Italy, 22-24 May 2017), "ISPRS. The International Archives of the Photogrammetry, Remote Sensing and Spatial Information Sciences", Vol. XLII-5/W1 (2017) 283290.

Donatella Fiorani - Marta Acierno: Innovative Tools for Managing Historical Buildings: the Use of Geographic Information System and Ontologies for Historical Centers. In: "ISPRS. International Archives of the Photogrammetry, Remote Sensing and Spatial Information Sciences", XLII, 2019. 21-27.

Donatella Fiorani - Silvia Cutarelli - Adalgisa Donatelli Annarita Martello: Vulnerabilità dei centri storici. Validazione della scheda Unità Urbana del sistema Carta del Rischio tramite la sua applicazione su due centri laziali. Materiali e strutture. Problemi di conservazione n.s. 8 (2019) 16. 71-96.

Fred Fonseca - James Martin: Toward an Alternative Notion of Information Systems Ontologies: Information Engineering as a Hermeneutic Enterprise. Journal of the American Society for Information Science and Technology 56 (2005) 46-57.

Functional Requirements for Bibliographic Records: Final Report / IFLA Study Group on the Functional Requirements for Bibliographic Records. - München: K.G. Saur, 1998. (UBCIM Publications, New Series; v. 19) Available at <http://www.ifla.org/ VII/s13/frbr/frbr.htm> or <http://www.ifla.org/VII/s13/frbr/frbr. pdf $>$ (Accessed 29 December 2019)

Thomas Gruber: A Translation Approach to Portable Ontology Specifications. Knowledge Acquisition 5 (1993) 2. 199-220.

Nicola Guarino - Pierdaniele Giaretta: Ontologies and Knowledge Bases: Towards a Terminological Clarification. In: Nicholas Mars (ed.): Towards Very Large Knowledge Bases: Knowledge Building and Knowledge Sharing. IOS Press, Amsterdam 1995. 25-32.

Hajnóczi Gyula: Mủemlékfelmérés. Budapest 1956.

Sergio Lagomarsino - Stefano Podestà: Metodologie per l'analisi di vulnerabilità delle chiese - In: L'Ingegneria Sismica in Italia, atti del $9^{\circ}$ Congresso Nazionale ANIDIS (Torino, 20-23 settembre 1999), pubblicazione cdrom 
Lagomarsino et al. 2004

Lelo-Chodějovská 2014

Linee Guida 2010

Marmor 2016

Negri 2008

Panzeri 2005

Salonia-Negri 2005

Schelbert 2017

Schöch 2013

Settis 2002

Simeone-Cursi-Acierno 2019

Stabel 2014

Studer- Benjamins-Fensel 1998

Tamborrino 2014

Thaller 1989

Vitali 2009
Sergio Lagomarsino - Stefano Podestà - Giandomenico Cifani Alberto Lemme: The $31^{\text {st }}$ October 2002 Earthquake in Molise (Italy): A New Methodology for the Damage and Seismic Vulnerability Survey of Churches. In: 13th World Conference on Earthquake Engineering, conference proceedings (Vancouver, Canada, 1-6 agosto 2004), pubblicazione cdrom

Keti Lelo - Eva Chodějovská (eds): Digital Methods for Urban History. Città e Storia 9 (2014) 1. 3-8.

Linee Guida per la valutazione e riduzione del rischio sismico del patrimonio culturale (Circolare n. 26 del 2 dicembre 2010), Gangemi, Roma 2010.

Max Marmor: Art History and the Digital Humanities. Zeitschrift für Kunstgeschichte 79 (2016) 2. 155-158.

Antonella Negri: Tecnologie informatiche per la conoscenza e la conservazione. In: G. Carbonara (ed): Trattato di restauro architettonico. Grandi temi di restauro. Secondo aggiornamento, vol. X. UTET Scienze Tecniche, Milano 2008. 63-103.

Matteo Panzeri: L'informatica documentaria per la storia del restauro: strumenti o metodi?: In: Chiara Piva - Ilaria Sgarbozza (eds), Il corpo dello stile. De Luca, Roma 2005. 169-187.

Paolo Salonia - Antonella Negri: Arkis-net: un web-GIS per il progetto di conservazione assistito. Archeologia e calcolatori (2005) 16. 167-176.

Georg Schelbert: Art History in the World of Digital Humanities: Aspects of a Difficult Relationship. Kunsttexte.de 4 (2017) 1. Available at <https://edoc.hu-berlin.de/bitstream/handle/18452/ 19404/Schelbert\%20-\%20final.pdf $>$ (Accessed 28 December 2019) Christof Schöch: Big? Smart? Clean? Messy? Data in the Humanities. Journal of Digital Humanities 2 (2013). Available at $<$ http://journalofdigitalhumanities.org/2-3/big-smart-cleanmessy-data-in-the-humanities/> (Accessed 29 December 2019)

Salvatore Settis: L'illusione dei beni digitali. Bollettino ICR n.s. (2002) 5. 7-17.

Davide Simeone - Stefano Cursi - Marta Acierno: BIM SemanticEnrichment for Built Heritage Representation. Automation in Construction 97 (2019) 122-137.

Peter Stabel: Opening a Pandora's Box? An Essay about the Pitfalls of Digital History and Digital Heritage: In: Tamborrino 2014. 29-38.

Rudi Studer - Richard Benjamins - Dieter Fensel: Knowledge Engineering: Principles and Methods. Data \& Knowledge Engineering 25 (1998) 161-198.

Rosa Tamborrino (ed): Digital Urban History. Università di Roma 3 - CROMA, Roma 2014.

Manfred Thaller: The Need of a Theory of Historical Computing. In: Peter Denley - Stephan Fogelvik - Charley Harvey (eds). History and Computing II. Manchester University Press, Manchester-New York 1989. 2-11.

Stefano Vitali: Dal documento alla risorsa: qualche riflessione metodologica sulle fonti storiche nell'era digitale. In: Matteo Panzeri - Angela Farruggia (eds): Fonti, metafonti e gis per l'indagine della struttura storica del territorio. Celig, Torino 2009. $13-18$. 


\title{
AZ ÉPÍTÉSZET MEGŐRZÉSÉNEK ÉS ESZKÖZEINEK ÁTALAKULÁSA
}

\author{
DIGITÁLIS RENDSZEREK HASZNÁLATA TÖRTÉNETI \\ ÉPÜLETEKEN VÉGZETT MÜEMLÉKI BEAVATKOZÁSOK ESETÉN
}

\section{Összefoglaló}

\begin{abstract}
A kutatásban azóta jelent meg innovatív szempontként a digitális technológiák használata az építészet és környezete tanulmányozásában, amióta a képek és alfanumerikus adatok dinamikus társítása (bemeneti és kimeneti formában) elkezdődött: az információk következtetések és algoritmusok révén létrejött különböző kombinációja, valamint az új adatok ezekből következő generálása megszabadította a digitalizálást szigorúan instrumentális szerepétől és önmagában új módszertani megközelítést hozott létre.

A közelmúltbeli építészeti kutatások tulajdonképpen „belülről” mutattak érdeklődést a probléma iránt, nemcsak a számítógépes eszközök alkalmazásával, hanem még tudatosabban a konfigurációval is foglalkoztak. A Sapienza egyetemi kutatócsoport munkájának célja kifejezetten történeti épületek bemutatására szolgáló ontológiák és következtetési modellek kifejlesztésére irányul azzal a szándékkal, hogy megvalósuljon a történeti központokra vonatkozó olasz nemzeti térinformatikai platform, az olasz Kulturális Örökség és Turizmus Minisztériuma kockázati térképe.

Ez a fajta kutatómunka módszertani problémák sorozatát foglalja magába, amelyek kifejezetten az építészettörténet szerepének meghatározására, valamint helyreállítási projektekben történő felhasználására irányulnak. Érveinket e tanulmányban fejtjük ki, elsősorban a következőkre összpontosítva: az új eljárásokból származó információ típusa és minősége; az új kutatási módszereket fellobbantó értelmező elemek; a költség-haszon arány az „,analóg” és a „digitális” megközelítés alkalmazása esetén; a kétféle (hagyományos és digitális) vizsgálati stratégia jövőbeli kilátásai. Ezeken túlmenően összefoglalásra kerül a kutatócsoport által kifejlesztett digitális kutatás mindkét területe (ontológia és kockázati térkép) is.
\end{abstract}

Kulcsszavak: digitális humán tudományok, építészeti konzerválás, építészettörténet módszertana, történeti városközpont

Received: 6 April 2020. Accepted: 8 May 2020

First published online: 24 June 2020 